\title{
Identification and Properties of 8-Hydroxyflavin - Adenine Dinucleotide in Electron-Transferring Flavoprotein from Peptostreptococcus elsdenii
}

\author{
Sandro GHISLA and Stephen G. MAYHEW
}

Department of Biological Chemistry, University of Michigan Medical School, Ann Arbor, Michigan

(Received September 18/November 27, 1975)

1. A new flavin prosthetic group has been isolated in pure form from the electron-transferring flavoprotein of Peptostreptococcus elsdenii. Its structure has been established as the FAD derivative of 7-methyl-8-hydroxyisoalloxazine:

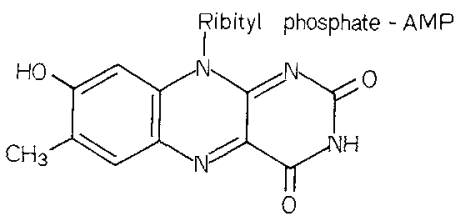

Proof of this structure has been obtained by chemical synthesis of 7-methyl-8-hydroxyisoalloxazine models, and by stepwise degradation of the native compound to 7 -methyl-8-hydroxyalloxazine. The orange chromophore is characterized by a strong absorption band with a maximum at $472 \mathrm{~nm}\left(\varepsilon=41000 \mathrm{M}^{-1} \mathrm{~cm}^{-1}\right)$ and a $\mathrm{p} K$ at 4.8 due to the ionisation of the $\mathrm{C}(8)$-OH group.

2. The properties of a series of functionally substituted derivatives of 8 -hydroxy flavins and lumichromes have been investigated to provide a basis for interpreting the effects of $\mathrm{pH}$ on the spectroscopic properties of the 8-hydroxy derivatives of FAD and FMN.

3. The 8-hydroxy derivative of FAD is bound by apo-D-amino acid oxidase; the complex shows no catalytic activity. The 8-hydroxy derivative of FMN is bound by apoflavodoxin to give a complex which has catalytic activity similar to that of native flavodoxin. The complex is reversibly reduced by dithionite, first to a relatively stable semiquinone and further to the dihydroflavin form.

The prosthetic group of flavoproteins is usually FAD or FMN bound non-covalently to the protein. However, in some enzymes the flavin is modified at position $8 \alpha$ and covalently linked through this position to the protein [1]. Two different modifications have also been discovered in flavins which are not bound covalently. A fraction of the total flavin in preparation of electron-transferring flavoprotein from Peptostreptococcus elsdenii and glycollate oxidase from pig

Abbreviations. NMR, nuclear magnetic resonance; EPR, electron paramagnetic resonance.

Enzymes. Glycollate oxidase or glycollate: $\mathrm{O}_{2}$ oxidoreductase (EC 1.1.3.1); D-amino-acid oxidase (EC 1.4.3.3); phosphodiesterase (EC 3.1.4.1).

Nomenclature. The abbreviations 8-OH-flavin, 8-OH-FAD, 8-OH-FMN, and 8-OH-riboflavin stand for flavin (7,8-dimethyl10-substituted-isoalloxazine) analogs in which the (8)- $\mathrm{CH}_{3}$ group is replaced by an $-\mathrm{OH}$ function (compare also structure 1 on Scheme 1). liver is green and contains an hydroxyl substituent at position 6 of the isoalloxanine moiety [2]. Early evidence for a second modified flavin in an enzyme from $P$. elsdenii which showed NADH dehydrogenase activity [3] was later confirmed and the flavin identified as the 8-hydroxy analogue of FAD (1a) [4]. More recently, the apoprotein of this NADH dehydrogenase has been shown to be identical with apoelectron-transferring flavoprotein [5].

In this paper we report in some detail the isolation and characterization of 8-OH-FAD (1a) and 8-OHFMN (1b) and the properties of model compounds which were synthesized to interpret the spectral properties of the coenzyme and their behaviour on apoflavoproteins. Other investigators have recently synthesized similar isoalloxazine derivatives by oxidation of 6,7-dihydroisoalloxazine [6] or by degradation of 8-substituted (iso)alloxazine [7]. 


\section{EXPERIMENTAL PROCEDURE}

\section{Chromatography and Electrophoresis}

Thin-layer chromatography was carried out on precoated silica gel/glass plates (Merck AG, Darmstadt) of $0.2 \mathrm{~mm}$ thickness. Electrophoresis was done on Whatman 3MM paper at pH $7(100 \mathrm{ml}$ pyridine and $5 \mathrm{ml}$ glacial acetic acid was adjusted to $\mathrm{pH} 7$ with ammonia and diluted to 1.01$)$ or $\mathrm{pH} 3(8 \mathrm{ml}$ pyridine was adjusted to $\mathrm{pH} 3$ with acetic acid and diluted to $1.01)$ with a Savant Instrument Inc. apparatus at a voltage of $22 \mathrm{~V} / \mathrm{cm}$. After electrophoresis, spots of flavin were detected by their fluorescence in ultraviolet light.

\section{Spectroscopic Methods}

Absorption spectra were recorded with Cary model 17 or 18 spectrophotometers using $1-\mathrm{ml}$ quartz cuvettes; anaerobic spectrophotometric titrations were carried out in the apparatus described previously [8]. Fluorescence emission and excitation spectra were recorded at $25^{\circ} \mathrm{C}$ with the ratio-recording fluorimeter described elsewhere [9]. Infrared spectra of $\mathrm{KBr}$ pellets were recorded on a Perkin-Elmer 237 instrument.

Nuclear magnetic resonance (NMR) spectra were recorded with a Varian T60 or A60 instrument. Values for chemical shifts (expressed as $\delta$ in ppm) are calibrated to tetramethylsilane as internal standard; values given in brackets refer to the number of protons and the position on the isoalloxazine ring of the function giving rise to the observed signal. The NMR spectrum of 8-OH-flavin isolated from electrontransferring flavoprotein was recorded after hydrolysis to the FMN level. About $200 \mu \mathrm{g}(0.5 \mu \mathrm{mol})$ of 8-OH-FMN (1b) was adjusted to $\mathrm{pH} 7$ with bicarbonate and then lyophilised to dryness. The residue was dissolved in approximately $100 \mu 199.97 \%$ ${ }^{2} \mathrm{H}_{2} \mathrm{O}$ (Thompson Packard Inc.). This solution was placed in an ultraprecision microcell (Kontes Glass Co., Vineland, N.J.) and measured with a Varian T60 instrument equipped with a phase lock unit and a time-average computer model Varian C 1024. 60100 scans were recorded, and for calibration a final measurement was made after addition of sodium tetradeutero-3-(trimethylsilyl)propionate.

Electron paramagnetic resonance (EPR) spectra were recorded with a Varian model V4500 instrument. For the preparation of the radical cations, solutions of flavin in $6 \mathrm{~N} \mathrm{HCl}$ were deoxygenated with argon and then carefully treated with $\mathrm{TiCl}_{3}$ in $6 \mathrm{~N} \mathrm{HCl}$ until maximal formation of the red colour of radical cation was observed. These solutions were then transferred anaerobically to flat quartz cells and the EPR spectra measured at ambient temperature.
Isolation and Degradation of the Enzyme Chromophore

The procedures for the preparation of electrontransferring flavoprotein from P.elsdenii [5], for extraction of the enzyme chromophores [2,3] and for the separation of FAD, 6-OH-FAD and 8-OHFAD (1a) by chromatography on DEAE-cellulose with $0.2 \mathrm{M}$ potassium phosphate buffer $\mathrm{pH} 5.9$ [2] have been described previously. The orange-coloured 8-OH-FAD (1a) was strongly adsorbed by DEAEcellulose and remained in a band near the top of the column. The DEAE-cellulose was extruded from the column, the orange resin cut out, suspended in water, poured into a second column and the adsorbed material eluted with $0.1 \mathrm{~N} \mathrm{HCl}$ and finally neutralised with solid $\mathrm{K}_{2} \mathrm{CO}_{3}$. Material from several preparations of electron-transferring flavoprotein (obtained from about $450 \mathrm{~g}$ dry bacterial cells) was combined $\left(40.5 \mathrm{ml}, A_{475 \mathrm{~nm}}=0.43\right)$, diluted to $100 \mathrm{ml}$ with $\mathrm{H}_{2} \mathrm{O}$, applied to a further column of DEAE-cellulose (Whatman DE-32, $10 \times 2 \mathrm{~cm}$ ) and the chromatographic and elution procedures described above were repeated. Thin-layer chromatography showed that the 8-OH-FAD (1a) obtained by this procedure was free of coloured or fluorescent contaminants.

$8-\mathrm{OH}-\mathrm{FMN}(1 \mathrm{~b})$ was prepared by treatment of 8-OH-FAD (1a) with phosphodiesterase (Naja naja venom from Sigma), the course of the reaction being followed by measuring changes in the absorption spectrum and fluorescence intensity. AMP was identified enzymically as a reaction product [3]. Although $8-O H-F M N(1 b)$ and AMP can be separated by thinlayer chromatography, large amounts of material were more conveniently separated by binding $8-\mathrm{OH}$ FMN (1b), $0.6 \mu \mathrm{mol})$ to apoflavodoxin $(0.65 \mu \mathrm{mol})$ and treating the mixture on a column $(50 \times 1 \mathrm{~cm})$ of Sephadex G-25 equilibrated with $0.001 \mathrm{M}$ phosphate buffer $\mathrm{pH}$ 6.5. The complex of 8-OH-FMN (1b) and apoflavodoxin was then dissociated by addition of methanol to $80 \%$ and heating at $60{ }^{\circ} \mathrm{C}$ for $10 \mathrm{~min}$. Denatured protein was removed by centrifugation $(15000 \times \mathrm{g}$ for $10 \mathrm{~min})$ and methanol was removed from the supernatant by distillation in vacuo. The free flavin was finally rechromatographed on Sephadex G-25 $(50 \times 1 \mathrm{~cm})$ equilibrated with water. 8-OH-riboflavin (1c) was prepared by hydrolysis of 8-OH-FMN (1b) with $1 \mathrm{~N} \mathrm{HCl}$ at room temperature in darkness. The course of the reaction was followed by thin-layer chromatography ( $c f$. legend to Table 1 , solvents $\mathrm{C}, \mathrm{D}$ ); at completion the solvent was evaporated in vacuo.

\section{Photodegradation}

of 8-OH-riboflavin and Identification of the Products

A solution $(1 \mathrm{ml})$ of $40 \mu \mathrm{M} 8$-OH-riboflavin (1c) (or $8-\mathrm{OH}-\mathrm{FMN}, 1 \mathrm{~b}$ ) was adjusted to $\mathrm{pH} \approx 3$ with acetic acid, placed in a quartz cuvette and then irra- 
diated with a tungsten-iodine lamp in a bath thermostated at $20^{\circ} \mathrm{C}$. The light intensity at the surface of the cuvette was $\approx 10^{8} \mathrm{erg} \mathrm{cm}^{-2} \mathrm{~s}^{-1}\left(10 \mathrm{~J} \mathrm{~cm}^{2} \mathrm{~s}^{-1}\right)$. The course of the reaction was followed spectrophotometrically [4] and by thin-layer chromatography ( $c f$. Table 1 , solvents $B, D$ ). After $120 \mathrm{~min}$ of irradiation no starting material, but several fastermoving spots, could be detected in the solution. The main blue fluorescent spot, 7 methyl-8-hydroxyalloxazine $\left(11, R_{3}, R_{4}=H\right)$, was scraped from the thinlayer plate, eluted with $1 \mathrm{~N}$ acetic acid, the solvent evaporated in vacuo and the residue dissolved in dilute bicarbonate solution, filtered and the filtrate used for the light absorption measurements.

\section{Enzyme Preparations}

Flavodoxin from P. elsdenii [10], apoflavodoxin [11], D-amino acid oxidase from pig kidney [12] and apo-D-amino acid oxidase [13] were prepared by published procedures.

\section{Synthesis of Flavin Compounds}

7,10-Dimethyl-8-hydroxyisoalloxanine (8-hydroxylumiflavin, $1, \mathrm{R}_{2}=\mathrm{CH}_{3}, \mathrm{R}_{3}=\mathrm{H}$ ). Trifluoroacetic anhydride $(32 \mathrm{~g}, 150 \mathrm{mmol})$ was added dropwise over a period of $10 \mathrm{~min}$ to a solution of $6.5 \mathrm{~g}(50 \mathrm{mmol})$ of 5-amino-o-cresol [2] in $30 \mathrm{ml}$ of tetrahydrofuran in a flask fitted with a condenser and stirrer. After $3 \mathrm{~h}$ at ambient temperature the solvent was evaporated in vacuo. Remaining traces of trifluoroacetic acid and anhydride were removed by azeotropic distillation with benzene. The crystalline residue was then dissolved in $50 \mathrm{ml}$ tetrahydrofuran; $2.3 \mathrm{~g}(0.1 \mathrm{~mol})$ sodium hydride were added in portions and the mixture was stirred for $15 \mathrm{~min}$. Subsequently, approximately $10 \mathrm{~g}$ $(70 \mathrm{mmol})$ methyl iodide were added and the mixture stirred for $4 \mathrm{~h}$ at ambient temperature. The solvent and excess methyl iodide were removed in vacuo, and the residue was hydrolyzed for $30 \mathrm{~min}$ at room temperature with $10 \mathrm{ml} 0.1 \mathrm{~N}$ sodium hydroxide. For the condensation, $6.2 \mathrm{~g}(0.1 \mathrm{~mol})$ boric acid and $9.4 \mathrm{~g}(60 \mathrm{mmol})$ violuric acid were added to this mixture, the $\mathrm{pH}$ was adjusted to 8.5 , the solution was diluted with water to a final volume of $50 \mathrm{ml}$, and it was then refluxed for $2 \mathrm{~h}$. The hot and dark-coloured reaction mixture was then acidified to about $\mathrm{pH} 3$ with glacial acetic acid and cooled in ice. The precipitate which formed was collected by filtration, suspended in a minimum volume of cold $10 \%$ bicarbonate solution, the mixture was filtered, the filtrate heated to boiling, and then treated with $2 \mathrm{~N}$ acetic acid until the beginning of precipitation. After cooling, the precipitate was collected by filtration, washed with dilute acetic acid and dried. Yield: $1.2 \mathrm{~g}$ of $1, \mathrm{R}_{2}=\mathrm{CH}_{3}, \mathrm{R}_{3}=\mathrm{H}(9 \%)$, m.p. $>340^{\circ} \mathrm{C}$.
Found: $\mathrm{C}$ 55.67, $\mathrm{H} 3.97, \mathrm{~N} 22.65 \% ; \mathrm{C}_{12} \mathrm{H}_{10} \mathrm{~N}_{4} \mathrm{O}_{3}$ $\left(M_{\mathrm{r}} 258.24\right)$ requires: $\mathrm{C} 55.81, \mathrm{H} 3.90, \mathrm{~N} 21.70 \%$. NMR $\left(\mathrm{CF}_{3} \mathrm{COOH}\right): \delta=8.32(6-\mathrm{H}), 7.70(9-\mathrm{H})$, $4.50\left(3 \mathrm{H}, 10-\mathrm{CH}_{3}\right)$ and $2.62 \mathrm{ppm}\left(3 \mathrm{H}, 7-\mathrm{CH}_{3}\right)$. Infrared $(\mathrm{KBr})$ : typical bands at 2790, 1690 and $1650 \mathrm{~cm}^{-1} \cdot m / e 258(M, 88 \%)$.

5-Ethylamino-o-cresol $\left(3, \mathrm{R}_{1}=\mathrm{C}_{2} \mathrm{H}_{5}, \mathrm{R}_{2}=\mathrm{H}\right)$. Pure 5-acetylamino-o-cresol $\left(3, \mathrm{R}_{1}=\mathrm{CH}_{3} \mathrm{CO}, \mathrm{R}_{2}=\right.$ H) [14], $4.3 \mathrm{~g}(26 \mathrm{mmol})$, dissolved in $200 \mathrm{ml}$ tetrahydrofuran, was reduced with an excess of $\mathrm{LiAlH}_{4}$ (about $3 \mathrm{~g}$ ) added in small portions over a period of $10 \mathrm{~min}$, then refluxed for $20 \mathrm{~min}$ and the remaining $\mathrm{LiAlH}_{4}$ decomposed with wet ether. After addition of $50 \mathrm{ml}$ water, celite and filtration, the product was extracted with $300 \mathrm{ml}$ ethyl acetate. The product (3, $\mathrm{R}_{1}=\mathrm{C}_{2} \mathrm{H}_{5}, \mathrm{R}_{2}=\mathrm{H}$ ) can be recrystallized from propan-2-ol/water.Yield:3.2 g $(80 \%)$. m.p. $112-114$ C.

7-Methyl-8-hydroxy-10-ethylisoalloxazine $\quad(1 \mathrm{~d}$, $\left.\mathrm{R}_{1}=\mathrm{C}_{2} \mathrm{H}_{5}, \mathrm{R}_{3}=\mathrm{H}\right)$. 5-Ethylamino-o-cresol (3, $\mathrm{R}_{1}$ $\left.=\mathrm{C}_{2} \mathrm{H}_{5}, \mathrm{R}_{2}=\mathrm{H}\right) 1.0 \mathrm{~g}(66 \mathrm{mmol})$ was condensed with violuric acid $\left(6, \mathrm{R}_{3}, \mathrm{R}_{4}=\mathrm{H}\right)(1.1 \mathrm{~g}, 70 \mathrm{mmol})$ in the presence of sodium metaborate $(3 \mathrm{~g}, 7.8 \mathrm{mmol})$ by refluxing in $50 \mathrm{ml}$ water $(\mathrm{pH} 8)$ for $2 \mathrm{~h}$. The reaction mixture was worked up as described for 7,10-dimethyl-8-hydroxyisoalloxazine). NMR ( $\mathrm{CF}_{3}$ $\mathrm{COOH}): \delta=8.28(6-\mathrm{H}), 7.68(9-\mathrm{H}), 4.95$ (quartet, $\left.2 \mathrm{H}, 10-\mathrm{CH}_{2}-\right), 2.62\left(7-\mathrm{CH}_{3}\right)$, and $1.84 \mathrm{ppm}$ (triplet, $\left.3 \mathrm{H}, 10-\mathrm{CH}_{2}-\mathrm{CH}_{3}\right) \cdot \mathrm{m} / \mathrm{e} 272(\mathrm{M}, 11 \%)$.

3,7-Dimethyl-8-hydroxy-10-ethylisoalloxazine $\quad(1$, $\mathrm{R}_{1}=\mathrm{C}_{2} \mathrm{H}_{5}, \mathrm{R}_{3}=\mathrm{CH}_{3}$ ) was synthesized from 3 , $\mathrm{R}_{1}=\mathrm{C}_{2} \mathrm{H}_{5}, \mathrm{R}_{2}=\mathrm{H}(600 \mathrm{mg}, 4 \mathrm{mmol})$ and monomethylvioluric acid $\left(6, \mathrm{R}_{3}=\mathrm{CH}_{3}, \mathrm{R}_{4}=\mathrm{H}\right)(770 \mathrm{mg}$, $4.1 \mathrm{mmol})$ in the presence of sodium borate $(2.0 \mathrm{~g}$, $5 \mathrm{mmol}$ ) as described for the first and third compounds above. Yield $110 \mathrm{mg},(10 \%)$ m.p. $350-352^{\circ} \mathrm{C}$ dec. $\operatorname{NMR}\left(\mathrm{CF}_{3} \mathrm{COOH}\right): \delta=8.25(6-\mathrm{H}), 7.66(9-\mathrm{H}), 4.91$ (quartet, $2 \mathrm{H}, 10-\mathrm{CH}_{2}$ ), 3.73 (singlet, 3- $\mathrm{CH}_{3}$ ), 2.63 $\left(7-\mathrm{CH}_{3}\right.$ ) and $1.80 \mathrm{ppm}$ (triplet, $3 \mathrm{H}, 10-\mathrm{CH}_{2}-\mathrm{CH}_{3}$ ).

$\mathrm{N}$-acetyl-2-nitro-5-methoxy-p-toluidine. $N$-Acetyl3 -methoxy-p-toluidine (4) $(2.0 \mathrm{~g}, 11 \mathrm{mmol})$ was nitrated in $40 \mathrm{ml}$ glacial acetic acid with $0.8 \mathrm{ml} 70 \%$ $\mathrm{HNO}_{3}$. The mixture was warmed at $70{ }^{\circ} \mathrm{C}$ for $5 \mathrm{~min}$, three parts of water were added and the crystals which formed on cooling were collected, washed repeatedly with water, and recrystallized from ethanol to yield $2.1 \mathrm{~g}(84 \%)$ of the pure compound, m.p. $135-137^{\circ} \mathrm{C}$. Found: C 53.44, H 5.45, N $12.52 \%, \mathrm{C}_{10} \mathrm{H}_{12} \mathrm{~N}_{2} \mathrm{O}_{4}$ $\left(M_{\mathrm{r}} 224.24\right)$ requires: C 53.56, H 5.40, N $12.49 \%$.

7-Methyl-8-methoxy-10-ethyl isoalloxanine (8). 2-Nitro-5-methoxy- $N$-acetyl-p-toluidine ( $c f$. last compound above) $(1.0 \mathrm{~g}, 4.45 \mathrm{mmol})$ was slowly added with the exclusion of moisture to $50 \mathrm{ml}$ dry tetrahydrofuran which contained $\approx 2 \mathrm{~g} \mathrm{LiAlH}_{4}$. The mixture was stirred for $18 \mathrm{~h}$ at $35^{\circ} \mathrm{C}$, and the excess $\mathrm{LiAlH}_{4}$ was then destroyed by the careful addition of water. Celite was added, the mixture filtered and washed repeatedly with tetrahydrofuran 
and the combined filtrates were evaporated to give the brown oily residue of the phenylene diamine (5). This compound was immediately condensed with $700 \mathrm{mg}$ alloxane (7) in $100 \mathrm{ml}$ glacial acetic acid containing $2 \mathrm{~g}$ boric acid according to known procedures [15]. Yield of $8: 540 \mathrm{mg}(45 \%)$, m.p. $341-344{ }^{\circ} \mathrm{C}$ dec. Found: C 58.84, H 4.89, N $19.61 \% ; \mathrm{C}_{14} \mathrm{H}_{14} \mathrm{~N}_{4} \mathrm{O}_{3}$ $\left(M_{\mathrm{r}} 286.29\right)$ requires: C $58.74, \mathrm{H} 4.93, \mathrm{~N} 19.57 \%$. $\mathrm{NMR}\left(\mathrm{CF}_{3} \mathrm{COOH}\right): \delta=8.23(6-\mathrm{H}), 7.48(9-\mathrm{H})$, 4.36 (singlet, $8-\mathrm{O}-\mathrm{CH}_{3}$ ), 2.61 (singlet, $7-\mathrm{CH}_{3}$ ) and $1.84 \mathrm{ppm}$ (triplet, $10-\mathrm{CH}_{2} \mathrm{CH}_{3}$ ).

$\mathrm{N}$-Acetyl-3-methoxy-p-toluidine $\left(3, \mathrm{R}_{1}=\mathrm{CH}_{3} \mathrm{CO}\right.$, $\left.\mathrm{R}_{2}=\mathrm{CH}_{3}\right)$. 5-Acetylamino-o-cresol $\left(3, \mathrm{R}_{1}=\mathrm{CH}_{3} \mathrm{CO}\right.$, $\left.\mathrm{R}_{2}=\mathrm{H}\right)(5.0 \mathrm{~g}, 30 \mathrm{mmol})$ dissolved in $50 \mathrm{ml} 1 \mathrm{~N}$ $\mathrm{NaOH}$, was alkylated by slow addition of $10 \mathrm{ml}$ dimethylsulfate in $30 \mathrm{ml}$ methanol with stirring, while maintaining an alkaline $\mathrm{pH}$ by titration with $1 \mathrm{~N}$ $\mathrm{NaOH}$. After 30 min the precipitate which formed was removed by filtration, washed with water, and recrystallized from ethanol/water. Yield: $4.4 \mathrm{~g}(83 \%)$, m.p. $117-119{ }^{\circ} \mathrm{C}$. Found: C 67.06, H 7.34, N 7.85\%; $\mathrm{C}_{10} \mathrm{H}_{13} \mathrm{NO}_{2}\left(M_{\mathrm{r}} 179.24\right)$ requires: C 67.01, H 7.32, $\mathrm{N} 7.81 \%$.

7-Methyl-8-acetoxy-10-ethylisoalloxazine (10). The 8-OH-flavin (1d, $\left.\mathrm{R}_{1}=\mathrm{C}_{2} \mathrm{H}_{5}, \mathrm{R}_{3}=\mathrm{H}\right)(100 \mathrm{mg})$, was acetylated in a mixture of $3 \mathrm{ml}$ acetic anhydride and $1 \mathrm{ml}$ acetic acid, by heating at $100{ }^{\circ} \mathrm{C}$ for $30 \mathrm{~min}$ in the presence of catalytic amounts of $\mathrm{HClO}_{4}$. After removal of the solvents the product was crystallized by addition of ether and recrystallized from glacial acetic acid. Yield $95 \mathrm{mg}(83 \%) \mathrm{m} . \mathrm{p} .>300^{\circ} \mathrm{C}$ dec. Found: C 57.06, $\mathrm{H} 4.61, \mathrm{~N} 17.73 \% ; \mathrm{C}_{15} \mathrm{H}_{14} \mathrm{~N}_{4} \mathrm{O}_{4}$ $\left(M_{\mathrm{r}} 314.30\right)$ requires: C 57.32, H 4.49, N 17.83\%.

7-Methyl-8-tosyloxy-10-ethylisoalloxazine (cf. 10 , $\mathrm{R}_{1}=\mathrm{C}_{2} \mathrm{H}_{5}, \mathrm{R}_{3}=\mathrm{H}$, and $\mathrm{C}_{7} \mathrm{H}_{7} \mathrm{SO}_{2}$ at position $\mathrm{C}(8)-\mathrm{O}$ instead of $\left.\mathrm{CH}_{3} \mathrm{CO}\right)$. 1d, $\mathrm{R}_{1}=\mathrm{C}_{2} \mathrm{H}_{5}, \mathrm{R}_{3}=\mathrm{H}(200 \mathrm{mg}$, $0.7 \mathrm{mmol}$ ) was tosylated with $p$-toluenesulfonyl chloride $(250 \mathrm{mg}, 1.3 \mathrm{mmol})$ in $2 \mathrm{ml}$ absolute pyridine at $60{ }^{\circ} \mathrm{C}$ for $5 \mathrm{~min}$. This solution was then cooled, poured into $50 \mathrm{ml}$ of cold water; the precipitate which formed was removed by filtration and then washed successively with dilute acetic acid, water and ether. The crude material was recrystallized from dioxane/diethyl ether. Yield; $295 \mathrm{mg}(95 \%)$, p.m. $265-267^{\circ} \mathrm{C}$. Found: $\mathrm{C} 56.26, \mathrm{H} 4.46, \mathrm{~N} 13.18 \% ; \mathrm{C}_{20} \mathrm{H}_{18} \mathrm{~N}_{4} \mathrm{O}_{5} \mathrm{~S}$ $(M, 426.45)$ requires: $\mathrm{C} 56.33, \mathrm{H} 4.25, \mathrm{~N} 13.14 \%$; NMR $\left(\mathrm{CF}_{3} \mathrm{COOH}\right) ; \delta=8.40$ (2 protons, $6 \mathrm{H}$ and $9 \mathrm{H}$ ), 7.20 (9-tosyl-2,3-H), 5.10 (quartet, $10-\mathrm{CH}_{2}$ ), $2.55\left(7-\mathrm{CH}_{3}\right), 2.38\left(\right.$ tosyl- $\left.\mathrm{CH}_{3}\right)$ and $1.83 \mathrm{ppm}$ (triplet, $\left.10-\mathrm{CH}_{2}-\mathrm{CH}_{3}\right)$.

3,7-Dimethyl-8-methoxy-10-ethylisoalloxazine (9). Alkylation of 8 and of $1 \mathrm{~d}, \mathrm{R}_{1}=\mathrm{C}_{2} \mathrm{H}_{5}, \mathrm{R}_{3}=\mathrm{CH}_{3}$, with methyl iodide in absolute dimethylformamide in the presence of potassium carbonate [16] yields the same product 9 , as judged by the identity of melting point $\left(303-306^{\circ} \mathrm{C}, \mathrm{dec}\right.$.), NMR, and light absorption spectra and of behaviour on thin-layer chromatography (cf. Table 1). NMR $\left(\mathrm{CF}_{3} \mathrm{COOH}\right)$ : $\delta=8.24(6-\mathrm{H}) ; 7.5(9-\mathrm{H}), 5.02$ (quartet, $10-\mathrm{CH}_{2}-$ ), 4.36 (singlet, 8- $\mathrm{OCH}_{3}$ ), 3.73 (singlet, 3- $\mathrm{CH}_{3}$ ), 2.60 $\left(7-\mathrm{CH}_{3}\right)$ and $1.84 \mathrm{ppm}$ (triplet, $10-\mathrm{CH}_{2}-\mathrm{CH}_{3}$ ). Infrared $(\mathrm{KBr})$ : Bands at $1690,1645,1570,1535$ and $1245 \mathrm{~cm}^{-1}$. m/e $300(M, 54 \%)$.

Violuric Acids (5-Nitrosopyrimidines) (6), $\mathrm{R}=$ $\mathrm{Hy} ; \mathrm{CH}_{3} ; \mathrm{R}_{4}=\mathrm{H}$ and $\mathrm{CH}_{3}$, and the required barbituric acids were synthesized according to published procedures [17-19].

1,3,7-Trimethyl-8-hydroxyalloxazine $\left(11, \mathrm{R}_{3}, \mathrm{R}_{\mathbf{4}}=\right.$ $\left.\mathrm{CH}_{3}\right)$. A mixture of $14 \mathrm{~g}(75 \mathrm{mmol})$ 1,3-dimethylvioluric acid $\left(6, \mathrm{R}_{3}, \mathrm{R}_{4}=\mathrm{CH}_{3}\right), 10.6 \mathrm{~g}(86 \mathrm{mmol})$ 5-amino-o-cresol (2), and $30 \mathrm{~g}(52 \mathrm{mmol})$ sodium borate in $120 \mathrm{ml}$ water was adjusted to $\mathrm{pH} 8.5$ and refluxed for $2.5 \mathrm{~h}$. The dark brown solution was filtered hot, the filtrate was acidified to $\mathrm{pH} \approx 4$ with glacial acetic acid and cooled in ice. The precipitate was washed with dilute acetic acid, methanol and acetone, and dried in a vacuum to yield $2.5 \mathrm{~g}$ of $11, \mathrm{R}_{3}, \mathrm{R}_{4}=\mathrm{CH}_{3},(9 \%)$. For elemental analysis the compound was repeatedly recrystallized from $0.1 \mathrm{~N}$ $\mathrm{NaOH} /$ dilute acetic acid. m.p. $>300^{\circ} \mathrm{C}$ dec. Found: C 57.46, H 4.31, N $20.61 \% ; \mathrm{C}_{13} \mathrm{H}_{12} \mathrm{~N}_{4} \mathrm{O}_{3}\left(M_{\mathrm{r}} 272.27\right)$ requires: $\mathrm{C} 57.35, \mathrm{H} 4.44, \mathrm{~N} 20.58 \%$. NMR $\left(\mathrm{CF}_{3^{-}}\right.$ $\mathrm{COOH}): \delta=8.30(6-\mathrm{H}), 7.73(9-\mathrm{H}), 4.03$ and 3.76 $\left(1-\mathrm{CH}_{3}\right.$ and $\left.3-\mathrm{CH}_{3}\right)$, and $2.73\left(7-\mathrm{CH}_{3}\right)$. m/e $272(\mathrm{M}$, $100 \%$ ).

7-Methyl-8-hydroxyalloxazine ("8-hydroxylumichrome') (11, $\left.\mathrm{R}_{3}, \mathrm{R}_{4}=\mathrm{H}\right)$ was synthesized from 5 amino-o-cresol (2) and violuric acid $\left(6, \mathrm{R}_{3}, \mathrm{R}_{4}=\mathrm{H}\right.$ ) as described for the previous compound above. The crude product (yield $10 \%$ ) can be readily recrystallized as the disodium salt. m.p. $>300{ }^{\circ} \mathrm{C}$ dec. Found: C 54.09, $\mathrm{H} 3.38, \mathrm{~N} 22.72 \% ; \mathrm{C}_{11} \mathrm{H}_{8} \mathrm{~N}_{4} \mathrm{O}_{3}\left(M_{\mathrm{r}} 244.21\right)$ requires: $\mathrm{C} 54.10, \mathrm{H} 3.30, \mathrm{~N} 22.94 \%$.

1,3,7-Trimethyl-8-benzyloxyalloxanine $\left(12, \mathrm{R}_{3}\right.$, $\mathrm{R}_{4}=\mathrm{CH}_{3}, \mathrm{R}_{2}=\mathrm{CH}_{2}-\mathrm{C}_{6} \mathrm{H}_{5}$ ), and 1,3,7-trimethyl8-methoxyalloxazine $\left(12, \mathrm{R}_{3}, \mathrm{R}_{4}=\mathrm{CH}_{3}, \mathrm{R}_{2}=\mathrm{CH}_{3}\right)$. Benzylation of $11, \mathrm{R}_{3}, \mathrm{R}_{4}=\mathrm{CH}_{3}$, occurs at position $\mathrm{C}(8)-\mathrm{O}$ under the conditions described by Hemmerich [16] for the alkylation of lumiflavins (absolute dimethylformamide/benzyl bromide/potassium carbonate). Yield $90 \%$ m.p. $255-256{ }^{\circ} \mathrm{C}$. Found: C $66.26, \mathrm{H} 4.96, \mathrm{~N} 15.41 \% ; \mathrm{C}_{20} \mathrm{H}_{18} \mathrm{~N}_{4} \mathrm{O}_{3}\left(M_{\mathrm{r}} 362.39\right)$ requires: $\mathrm{C} 66.29, \mathrm{H} 5.01, \mathrm{~N} 15.46 \%$. NMR $\left(\mathrm{C}^{2} \mathrm{HCl}_{3}\right)$ : $\delta=5.24\left(2 \mathrm{H}, 8-\mathrm{O}-\mathrm{CH}_{2}-\right), 3.75$ and $3.53\left(1-\mathrm{CH}_{3}\right.$ and $\left.3-\mathrm{CH}_{3}\right)$, and $2.45 \mathrm{ppm}\left(7-\mathrm{CH}_{3}\right)$. Methylation of $11, \mathrm{R}_{3}, \mathrm{R}_{4}=\mathrm{CH}_{3}$, with methyl iodide yields analogously $12, \mathrm{R}_{2}, \mathrm{R}_{3}, \mathrm{R}_{4}=\mathrm{CH}_{3}$, which has physical properties closely similar to those of the benzylation product $12, \mathrm{R}_{2}=\mathrm{CH}_{2}-\mathrm{C}_{6} \mathrm{H}_{5}$. Formation of 15 , $\mathrm{R}_{1}=\mathrm{CH}_{3}$ was not observed.

1,3,7-Trimethyl-5-acetyl-8-acetoxy-10,5-dihydroalloxazine (13) was prepared by reductive acetylation of $1.0 \mathrm{~g}$ of $11, \mathrm{R}_{3}, \mathrm{R}_{4}=\mathrm{CH}_{3}$ according to the method described by Dudley and Hemmerich for related 
alloxazines [20]. Recrystallization occurred from dimethylformamide/water. Yield $1.2 \mathrm{~g},(87 \%)$, m.p. $171-176^{\circ} \mathrm{C}, \lambda_{\max }(\mathrm{MeOH}) 310 \mathrm{~nm}$. NMR: $\left(\mathrm{C}^{2} \mathrm{HCl}_{3} /\right.$ $\left.\mathrm{CF}_{3} \mathrm{COOH}=9 / 1\right): \quad \delta=8.0$ and $6.96(6-\mathrm{H}$ and 9-H), 3.58 and $3.43\left(1-\mathrm{CH}_{3}\right.$ and $\left.3-\mathrm{CH}_{3}\right), 2.40,2.27$ and $2.20 \mathrm{ppm} \quad\left(5-\mathrm{CO}-\mathrm{CH}_{3}, \quad 7-\mathrm{CH}_{3}\right.$ and $8-\mathrm{O}$ $-\mathrm{COCH}_{3}$ ).

I,3,7,10-Tetramethyl-8-oxoalloxazine $\left(15, \mathrm{R}_{1}=\right.$ $\left.\mathrm{CH}_{3}\right)$. A solution of $200 \mathrm{mg}(0.53 \mathrm{mmol}) 13$ in $50 \mathrm{ml}$ absolute tetrahydrofuran was treated with $50 \mathrm{mg}$ $(2.2 \mathrm{mmol}) \mathrm{NaH}$ and stirred at $24^{\circ} \mathrm{C}$ for $10 \mathrm{~min}$. $0.2 \mathrm{ml}(2.1 \mathrm{mmol})$ dimethylsulphate were then added, the mixture stirred at $24{ }^{\circ} \mathrm{C}$ for a further $5 \mathrm{~h}$, and then treated with $0.5 \mathrm{ml} 1 \mathrm{~N}$ acetic acid to destroy the excess sodium hydride. The solvent was then evaporated under vacuum to yield an oily product (14) which was dissolved in $20 \mathrm{ml} 6 \mathrm{~N} \mathrm{HCl}$. Sodium nitrite (200 mg) was added to this solution, the solvent evaporated under a vacuum, the residue dissolved in $10 \mathrm{ml}$ of water and the resulting solution adjusted to $\mathrm{pH} 8$ with bicarbonate. A small amount of 12 , $\mathrm{R}_{2}, \mathrm{R}_{3}, \mathrm{R}_{4}=\mathrm{CH}_{3}$, precipitated and was separated by filtration. The filtrate was made saturated with ammonium sulphate and then extracted thoroughly with chloroform. The extracts were dried over sodium sulphate, the solvent evaporated under vacuum and the residue treated with $20 \mathrm{ml}$ acetone. On standing, red crystals of $15, \mathrm{R}_{1}=\mathrm{CH}_{3}$ separated, and were collected by filtration. Yield $120 \mathrm{mg}$ ( $79 \%$ ) m.p. $273-278{ }^{\circ} \mathrm{C}$ dec. For elemental analysis the compound was recrystallised from acetonitrile/2-propylether. Found: C 58.68, H 5.02, N $19.69 \% ; \mathrm{C}_{14} \mathrm{H}_{14} \mathrm{~N}_{4} \mathrm{O}_{3}$ $\left(M_{\mathrm{r}} 286.29\right)$ requires: $\mathrm{C} 58.74, \mathrm{H} 4.93, \mathrm{~N} 19.57 \%$. NMR $\left(\mathrm{CF}_{3} \mathrm{COOH}\right): \delta=8.20(6-\mathrm{H}), 7.60(9-\mathrm{H})$, $4.50,4.00$ and 3.70 ( 3 methyl groups, $10-\mathrm{CH}_{3}, 1-\mathrm{CH}_{3}$ and $\left.3-\mathrm{CH}_{3}\right)$, and $2.60 \mathrm{ppm}\left(7-\mathrm{CH}_{3}\right)$. Infrared $(\mathrm{KBr})$ : characteristic bands at 1720,1665 and $1620 \mathrm{~cm}^{-1}$. $m / e 286(M, 100 \%)$.

\section{RESULTS AND DISCUSSION}

\section{Separation, Degradation and Identification of the Enzyme Chromophore}

When extracts of electron-transferring flavoprotein are treated on DEAE-cellulose as described in Experimental Procedure, three coloured bands are separated. In order of their elution from the column, these bands are yellow, green and orange. The chromophores in the first two have been identified as FAD and 6-OH-FAD respectively [2]. Several lines of evidence indicated that the orange chromophore in the third band is also a flavin at the level of FAD; it is bound by the apoproteins of D-amino acid oxidase and electron-transferring flavoprotein, which are specific for FAD and FAD derivatives, and it can be degraded stepwise by procedures which are known to hydrolyse FAD. The changes in the properties of the chromophore at each step resemble those during the sequential degradation of FAD to FMN, riboflavin and lumichrome. For example, phosphodiesterase (Naja naja venom) splits AMP from the chromophore and during the hydrolysis, the intensity of the visible absorption peak increases by $12 \%$, an amount comparable with the value observed on hydrolysis of FAD to FMN (11\% [21]). The orange product of this hydrolysis is bound by the apoprotein of $P$. elsdenii flavodoxin, thus providing strong evidence that it is an FMN derivative. Further mild hydrolysis gives a product which is not bound by apoflavodoxin, and which has physical properties resembling those of riboflavin (Table 1).

The absorption spectrum of the orange chromophore at the FAD, FMN and riboflavin levels depends on $\mathrm{pH}$ not only in the $\mathrm{pH}$ regions of the two $\mathrm{p} K \mathrm{~s}$ of isoalloxazine $(\mathrm{p} K \approx 10$ and $\mathrm{p} K \approx 1$ [22]) but also around $\mathrm{pH}$ 5. This additional $\mathrm{pK}$ of 4.8 is due to the ionization of a weak acid, as was inferred

Table 1. Chromatographic and electrophoretic properties of 8-OH-riboflavin and of model compounds

The solvent systems were: (A) butanol/ethanol/1.0 M sodium acetate $\mathrm{pH} 6(6 / 3 / 1, \mathrm{v} / \mathrm{v} / \mathrm{v}) ;(\mathrm{B}) \mathrm{butanol} / \mathrm{ethanol} / \mathrm{water}(6 / 3 / 1 /$, v/v/v); (C) butanol/ethanol/2 $\mathrm{N}$ ammonia $(6 / 2 / 2, \mathrm{v} / \mathrm{v} / \mathrm{v})$; (D) butanol/acetic acid/water $(4 / 3 / 3, \mathrm{v} / \mathrm{v} / \mathrm{v})$. Electrophoretic mobilities are in arbitrary units and compared with the mobility of riboflavin; the mobility of riboflavin from the starting line is given in brackets. $(+)$ Mobility towards the anode; (-) mobility towards the cathode

\begin{tabular}{|c|c|c|c|c|c|c|}
\hline \multirow[t]{2}{*}{ Compound } & \multicolumn{4}{|c|}{$R_{\mathrm{F}}$ values in solvent } & \multicolumn{2}{|c|}{$\begin{array}{l}\text { Electrophoretic } \\
\text { mobility at }\end{array}$} \\
\hline & $\mathrm{A}$ & $\mathrm{B}$ & $\mathrm{C}$ & $\mathrm{D}$ & $\mathrm{pH} 3$ & $\mathrm{pH} 7$ \\
\hline Riboflavin & 0.48 & 0.30 & 0.70 & 0.33 & $(-10)$ & $(+1)$ \\
\hline FMN & 0 & 0 & - & 0.15 & +13.5 & +16 \\
\hline FAD & 0 & 0 & 一 & - & +9 & +14 \\
\hline $8 \alpha(\pi$-Histidyl)riboflavin [36] & & & & 0.10 & -24 & -7.5 \\
\hline $8-O H-r i b o f l a v i n(1 \mathrm{c})$ & 0.33 & 0.17 & 0.48 & 0.22 & -6.5 & +9 \\
\hline \multicolumn{7}{|l|}{ Main photodegradation product of $8-\mathrm{OH}$-ribo- } \\
\hline flavin (1c) & 0.87 & 0.89 & 0.65 & 0.81 & & \\
\hline 7-Methyl-8-OH-alloxazine $\left(11, \mathrm{R}_{\mathbf{3}}, \mathrm{R}_{4}=\mathrm{H}\right)$ & 0.87 & 0.89 & 0.65 & 0.81 & & \\
\hline 8-OH-lumiflavin (1d, $\left.\mathrm{R}_{1}=\mathrm{CH}_{3}, \mathrm{R}_{3}=\mathrm{H}\right)$ & 0.60 & 0.57 & 0.66 & 0.53 & & \\
\hline
\end{tabular}


from the relatively tight binding of the chromophore to DEAE-cellulose and from the electrophoretic properties of the chromophore at the riboflavin level: at $\mathrm{pH} 7$ the uncharged riboflavin does not migrate, while the orange chromophore moves towards the anode (Table 1); at $\mathrm{pH} \mathrm{3,} \mathrm{where} \mathrm{riboflavin} \mathrm{is}$ neutral, both compounds move very slowly towards the cathode. By comparison, 8-histidylriboflavin carries a positive charge at this $\mathrm{pH}$, and shows a much higher mobility (Table 1).

NMR and EPR spectra, which are detailed below, indicated that by comparison with normal flavin, the modified flavin lacks a methyl group. As pointed out previously [4], the replacement of the methyl group at position $\mathrm{C}-8$ of isoalloxazine by a phenolic hydroxyl would explain the physicochemical properties of the flavin. Therefore model flavins with this structure were synthesized in an unequivocal way. The spectroscopic properties of these 7-methyl8-hydroxy-10-alkylisoalloxazines (1d, Scheme 1) were shown to closely resemble those of the enzyme chromophore at the FMN and riboflavin levels [4] thus indicating the presence of the same chromophoric system. In analogy to the established acidic photodegradation of the ribityl side chain of riboflavin to lumichrome, the orange FMN and the orange riboflavin could be converted to the lumichrome derivative. This was isolated by thin-layer chromatography and its spectroscopic (Fig. 4 below) and chromatographic properties (Table 1) were characterized and shown to be indistinguishable from those of synthetic 7methyl-8-hydroxyalloxazine $\left(11, \mathrm{R}_{3}, \mathrm{R}_{4}=\mathrm{H}\right.$, Scheme 2 below). It could, therefore, be concluded that the orange chromophore of electron-transferring flavoprotein is 7-methyl-8-hydroxy-10(5'-ADP-ribityl)isoalloxazine (1a).

\section{Chemical Synthesis and Properties \\ of 8-Substituted (Iso)alloxazines}

The chemical synthesis of these (iso)alloxazines, as described in Experimental Procedure, is straightforward and leads to compounds of unequivocal structures. They have been characterized by combinations of conventional analytical methods (e.g. elemental analysis, NMR, EPR, infrared and visible spectroscopy). Since our first report [4], similar compounds have been obtained by Addink and Berends [6] by autoxidation of 6,7-dihydroalloxazine; they show physical characteristics which are in good agreement with those reported here. The synthetic pathway is outlined in Schemes 1 and 2 and only a few points which need further elaboration will be discussed here.

$\mathrm{N}$-substituted amino-o-cresols (3) are condensed with (monosubstituted) violuric acids (6) in the presence of boric acid and yield compounds 1 (Scheme 1); this reaction is discussed elsewhere $[15,17]$. This synthesis does not lead to the desired products when the $-\mathrm{OH}$ function of the cresol is blocked (e.g. 3, $\mathrm{R}_{2}=\mathrm{CH}_{3}$ ) and when both nitrogens of violuric acid (6) are substituted (e.g. 6, $\mathrm{R}_{3}, \mathrm{R}_{4}=\mathrm{CH}_{3}$ ). In these cases, and under the conditions used for the synthesis of compounds $1 \mathrm{~d}$, or when the condensation was attempted in acid medium, only unidentifiable products and tars are obtained. Since alkylation of compounds 1d may yield several isomers and disubstitution, flavins unequivocally substituted at the $\mathrm{C}(8)-\mathrm{O}$ function were obtained by condensation of the newly described methoxy-phenylene diamine (5) with alloxane by the method of Kuhn (cf. [15]). Methylation of compound 8 then occurs at N(3) and yields a product which is identical with the product of methylation of compound $1 \mathrm{~d}\left(\mathrm{R}_{1}=\mathrm{C}_{2} \mathrm{H}_{5}\right.$, $\mathrm{R}_{3}=\mathrm{CH}_{3}$ or $\mathrm{H}$ ). Thus the anion of compound 1 alkylates at $\mathrm{C}(8)-\mathrm{O}$ and not at $\mathrm{N}(1)-\mathrm{C}(2)=\mathrm{O}$. Similarly, acylation and tosylation of compound 1 occur at $\mathrm{C}(8)$-O.

The 8-OH-alloxazines $\left(11, \mathrm{R}_{3}, \mathrm{R}_{4}=\mathrm{CH}_{3}\right.$ or $\left.\mathrm{H}\right)$ were synthesized in an analogous way from $o$-aminocresol (2) and violuric acid $\left(6, \mathrm{R}_{3}, \mathrm{R}_{4}=\mathrm{CH}_{3}\right.$ or $\left.\mathrm{H}\right)$ (Scheme 2). As in the case of the attempted synthesis of $8 \alpha$-substituted isoalloxazines the condensation fails when the aminocresol (2) carries a substituent on the oxygen function $\left(\mathrm{R}_{2} \neq \mathrm{H}\right)$. Alkylation (and acylation) of the anion of compound $11\left(\mathrm{R}_{3}, \mathrm{R}_{4}=\right.$ $\mathrm{CH}_{3}$ ) occurs at $\mathrm{C}(8)-\mathrm{OH}$ and not at $\mathrm{N}(10)$ to yield compound 12 (compare mesomeric structures for the anion of 11 in Scheme 2). Therefore, for the synthesis of the desired N(1), N(10)-blocked 'paraquinoid' flavin $15\left(\mathrm{R}_{1}=\mathrm{CH}_{3}\right)$, the $\mathrm{C}(8)-\mathrm{OH}$ and $\mathrm{N}(5)-\mathrm{H}$ functions were protected by acylation of the reduced form of compound $11\left(\mathrm{R}_{3}, \mathrm{R}_{4}=\mathrm{CH}_{3}\right)$. Dudley and Hemmerich [20] have shown that acylation of reduced alloxazines occurs at $\mathrm{N}(5)$ and not at $\mathrm{N}(10)$; this finding, in connection with the NMR spectra, which show the presence of two acetyl functions, confirm the proposed structure of compound 13. Alkylation of 5-acetyl-5,10-dihydroalloxazines such as compound 13 with methyl iodide was found to occur predominantly at position $\mathrm{N}(10)$, to a minor extent at position $\mathrm{C}(4 \mathrm{a})$ and not at position $\mathrm{C}(4)=\mathrm{O}$ [20]; these products could readily be recognized by their NMR spectra. Compound 14 , obtained by methylation of compound 13, was converted to the acidstable compound $15\left(\mathrm{R}_{1}=\mathrm{CH}_{3}\right)$ by oxidation/hydrolysis with nitrous acid. The structure of compound $15\left(\mathrm{R}_{1}=\mathrm{CH}_{3}\right)$ is confirmed by elemental analysis, mass spectroscopy, NMR and electron absorption spectroscopy ( $c f$. Fig. 4 and details below). In particular, alkylation at position $\mathrm{C}(4 \mathrm{a})$ is excluded by NMR ; substitution at $\mathrm{C}(4)-\mathrm{O}$ is very improbable in view of the negative results of Jefcoate et al. [20], and should yield an acid-labile compound [20]. 


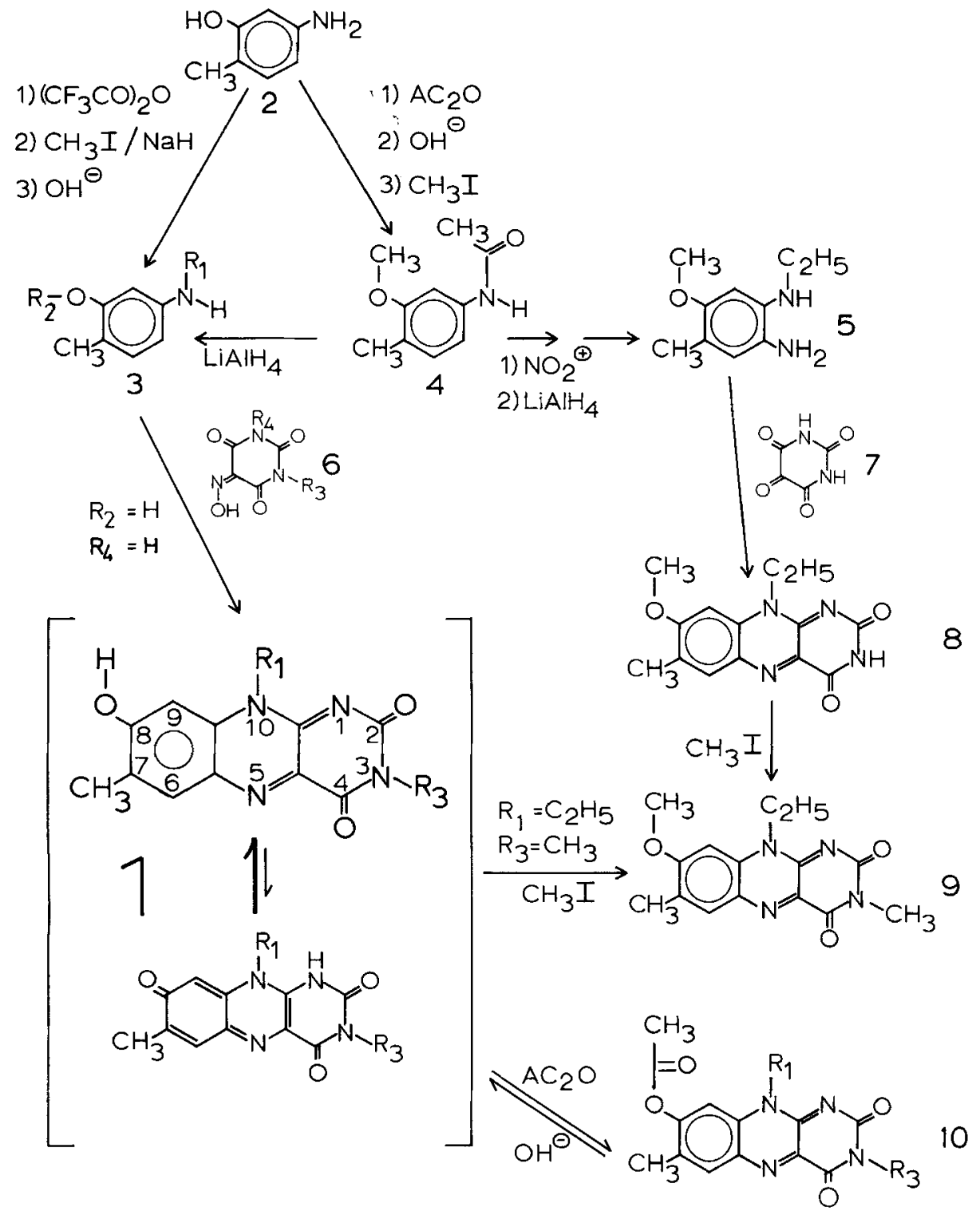

1 a) $R_{1}=$ ribityl-AMP; $R_{3}=H$

b) $\mathrm{R}_{1}=$ ribityl $-\mathrm{OPO}_{3} \mathrm{H}_{2} ; \mathrm{R}_{3}=\mathrm{H}$

c) $R_{1}=$ ribityl; $R_{3}=H$

d) $\mathrm{R}_{4}=\mathrm{CH}_{3}$ or $\mathrm{C}_{2} \mathrm{H}_{5}, \mathrm{R}_{3}=\mathrm{H}$ or $\mathrm{CH}_{3}$

Scheme 1

The unusually low $\mathrm{p} K$ of the phenolic $8-\mathrm{OH}$ function in compounds 1 ( $\mathrm{p} K=4.6$ for $1 \mathrm{~d}, 4.8$ for $1 \mathrm{~b}$, or 1c, cf. Table 2, compare with 2,4-dinitrophenol, $\mathrm{p} K=4.1)$ is an expression of the high electron deficiency of the isoalloxazine nucleus. It provides a direct estimate of the "acidity' of substituents at $\mathrm{C}(8)$, a property which has been deduced previously from a series of exchange and condensation reactions with the $\mathrm{C}(8)-\mathrm{CH}_{3}$ group of normal flavins $[23,24]$. The acetoxy substituent in compound 10 has accordingly a typical anhydride character; its hydrolysis is very rapid at $\mathrm{pH}$ values greater than 8 (e.g. $t_{1 / 2}=13 \mathrm{~min}$ at $\mathrm{pH} 9.5$ as in Fig. 1), leads to compounds 1 without formation of detectable intermediate adducts, and is subject to strong general catalysis by several anions and nitrogen bases. In contrast, hydrolysis of the 8-tosylate of compound $1 \mathrm{~d}$ is slow, comparable rates only being obtained at higher $\mathrm{pH}$ (e.g. $t_{1 / 2}=18 \mathrm{~min}$ at $\mathrm{pH} 12.5$ and $25^{\circ} \mathrm{C}$ ), and in addition methanolysis of this compound in the presence of sodium methylate yields only compound $1 \mathrm{~d}$ and not 9 . An hydrolysis reaction proceeding 


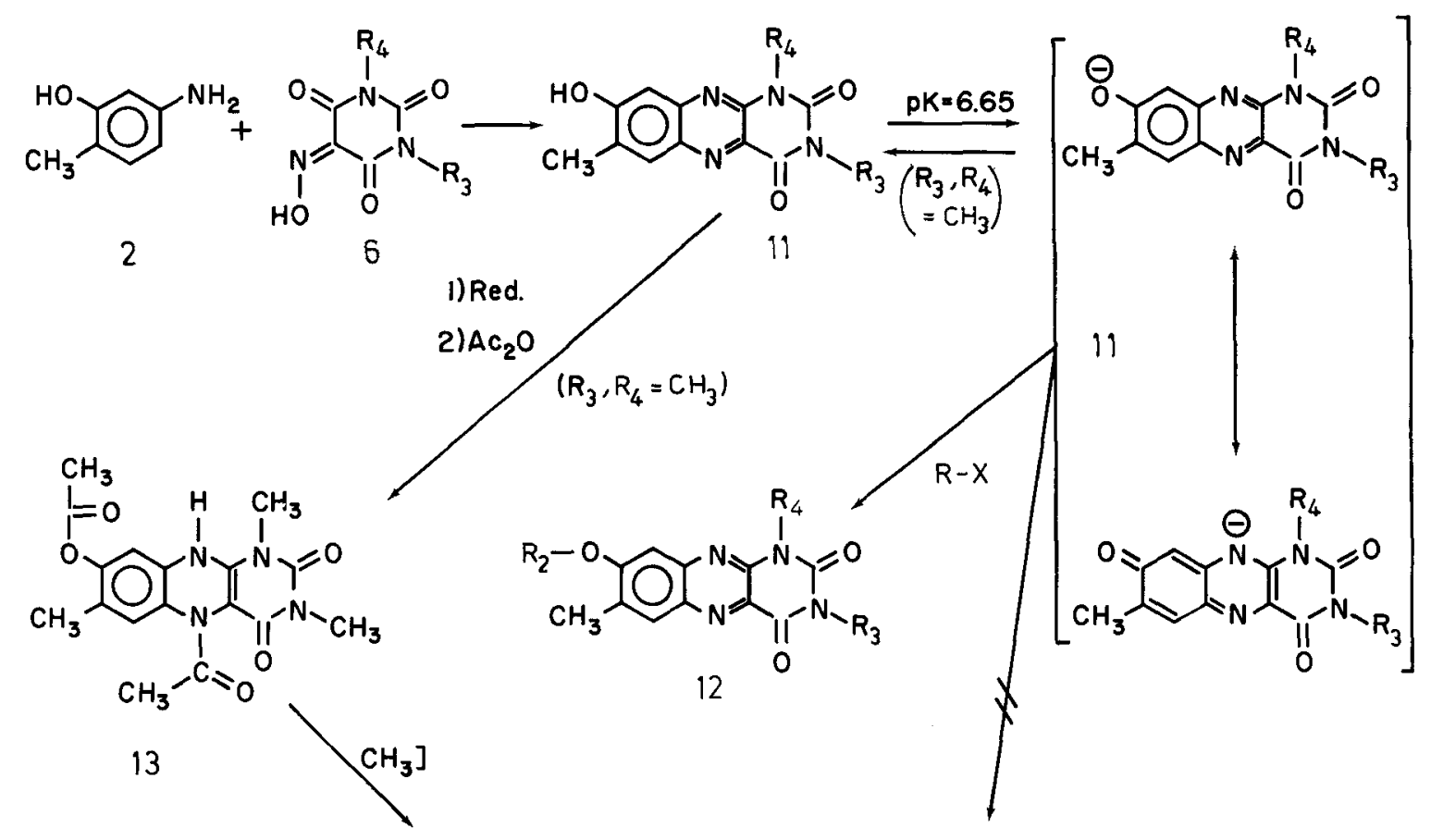<smiles>CC(=O)Oc1cc2c(cc1C)N(C(C)=O)c1c(c(=O)n(C)c(=O)n1C)N2C</smiles><smiles></smiles>

Scheme 2

through nucleophilic attack of the solvent at position $\mathrm{C}(8)$, such as has been described for 8-chloroisoalloxazines [17], does not occur to a detectable extent in the present cases. The $\mathrm{p} K$ difference between compounds $1 \mathrm{~b}, \mathrm{c}$ and $1 \mathrm{~d}$ can be attributed to an interaction of a side-chain hydroxyl group (in $1 b, c)$ with the $\mathrm{N}(1)-\mathrm{C}(2)=\mathrm{O}$ function.

\section{EPR and NMR Spectra}

When the enzyme chromophore at the FMN level is dissolved in $6 \mathrm{~N} \mathrm{HCl}$ and treated with $\mathrm{Ti}^{3+}$, a red compound is formed similar to the semiquinone intermediate of normal FMN. The intermediate is further reduced by an excess of $\mathrm{Ti}^{3+}$ to a colourless species which is assumed to be the cation of fully reduced $8-\mathrm{OH}$-flavin $(1 \mathrm{~b})$. The red intermediate has a resolved EPR signal (Fig. 2) with a total width of $\approx 44 \mathrm{G}$. By comparison, a total line width of $52 \mathrm{G}$ was found for riboflavin and FMN, $46 \mathrm{G}$ for $8 \alpha$ histidylriboflavin from succinate dehydrogenase [25] and $46.5 \mathrm{G}$ for $8 \alpha$-( $p$-chlorobenzoyl)riboflavin (spectrum not shown) synthesized according to Hemmerich et al. [24]. For reasons outlined earlier [25], the difference between the EPR-hyperfine pattern of the orange flavin radical cation and $8 \alpha$-histidyl-riboflavin or FMN and the 'loss' [25] of more than two ESR- active protons, provided an indication for a substantial modification possibly at position $C(8)$ of the coenzyme. The ESR spectrum of the orange FMN in ${ }^{2} \mathrm{H}_{2} \mathrm{O} / \mathrm{CF}_{3} \mathrm{COO}^{2} \mathrm{H}(1 / 1)$ has a total band width of $\approx 38 \mathrm{G}$ and suggested that more than one EPRactive proton has been exchanged with deuterium, i.e. $\mathrm{N}(5) \mathrm{H}$ and $\mathrm{C}(8)-\mathrm{OH}$. The EPR spectrum of the radical cation of 8-OH-lumiflavin (1d, $\mathrm{R}_{1}=\mathrm{CH}_{3}$, $\mathrm{R}_{3}=\mathrm{H}$ ) has a total width of $49.5 \mathrm{G}$ compared with $60 \mathrm{G}$ for lumiflavin [25] and provided confirmation of the modification at $\mathrm{C}(8)$. Finally, the spectra of the radical cation of 7-methyl-8-hydroxy-10-ethylisoalloxazine ( $1 \mathrm{~d}, \mathrm{R}_{1}=\mathrm{C}_{2} \mathrm{H}_{5}, \mathrm{R}_{3}=\mathrm{H}$ ), which have a total band width $(43.0 \mathrm{G}$ in $6 \mathrm{~N} \mathrm{HCl}$, and $37.5 \mathrm{G}$ in $\left.{ }^{2} \mathrm{H}_{2} \mathrm{O} / \mathrm{CF}_{3} \mathrm{COO}^{2} \mathrm{H}\right)$ and hyperfine pattern very similar to those of the spectra of the enzyme chromophore, further confirmed the structural assignment (Fig.2).

The NMR spectrum of the orange FMN in ${ }^{2} \mathrm{H}_{2} \mathrm{O}$ shows a single peak in the region of $\approx 1.8 \mathrm{ppm}$ corresponding to the $\mathrm{C}(7)-\mathrm{CH}_{3}$ group. In $\mathrm{CF}_{3} \mathrm{COO}^{2} \mathrm{H}$ a signal at $\approx 2.5 \mathrm{ppm}$ was observed in addition to the signals of the ribityl side chain at $4.0-5.5 \mathrm{ppm}$ and a further weak signal at $\approx 7.5 \mathrm{ppm}$ probably due to the $C(6)$ and $C(9)$ protons. No accurate integration was possible because of the small amount of material available $(\approx 0.5 \mu \mathrm{mol})$. However, a second methyl signal in the $1.6-3.2-\mathrm{ppm}$ region was considered 


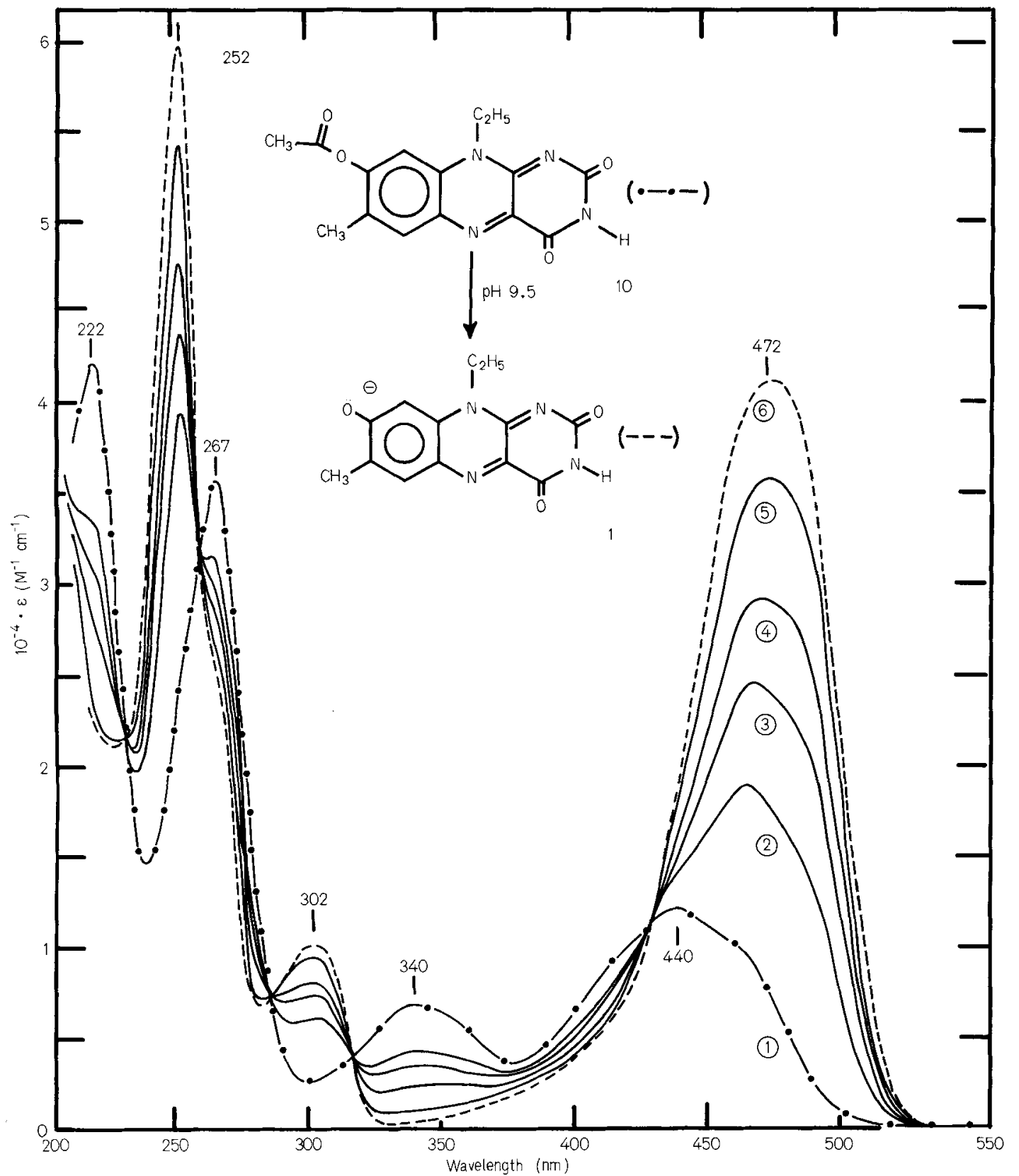

Fig. 1. Changes in the absorption spectrum during the conversion of the 8-acetoxyflavin (10) to the anion of the orange flavin (1). The 8-acetoxyflavin (10) in absolute methanol was diluted 20 -fold with $0.1 \mathrm{M}$ pyrophosphate buffer, $\mathrm{pH} 9.5$ at $24^{\circ} \mathrm{C}$, to give a solution of $20 \mu \mathrm{M}$. Curves $2,3,4,5$, and $6(-)$ were recorded $7,13.5,19,34$ and approximately $120 \mathrm{~min}$ after mixing. Curve $1(\bullet-\cdots)$ is compound $10(20 \mu \mathrm{M})$ in $0.1 \mathrm{M}$ phosphate buffer $\mathrm{pH} 7$

improbable since it would have required that the signals from both methyl groups would be coincident in the spectra of both the neutral and cationic forms of the molecule. The positions of the signals of the enzyme chromophore were found to be in appropriate agreement with those of the synthetic compounds (cf. Experimental Procedure).

\section{Light Absorption Properties}

The flavocoenzymes and the synthetic derivatives of the isoalloxazine molecule are characterized by their typical visible and ultraviolet absorption spectra and by their fluorescence emissions. The spectra of the orange flavins (1) in neutral solution (see [4] and curve 6 in Fig. 1) are strikingly different from the spectra of normal flavins (e.g. curve 1 in Fig. 1). In particular, the higher absorption coefficients and the dependence on the state of ionisation of the $8-\mathrm{OH}$ function (Table 2) indicate that the electronic distribution in the chromophore is strongly altered. The class of $8-\mathrm{OH}$ isoalloxazines (1) can be represented either in a 'phenolic' structure or in its tautomeric 'paraquinoid' form (Scheme 1, upper and lower 


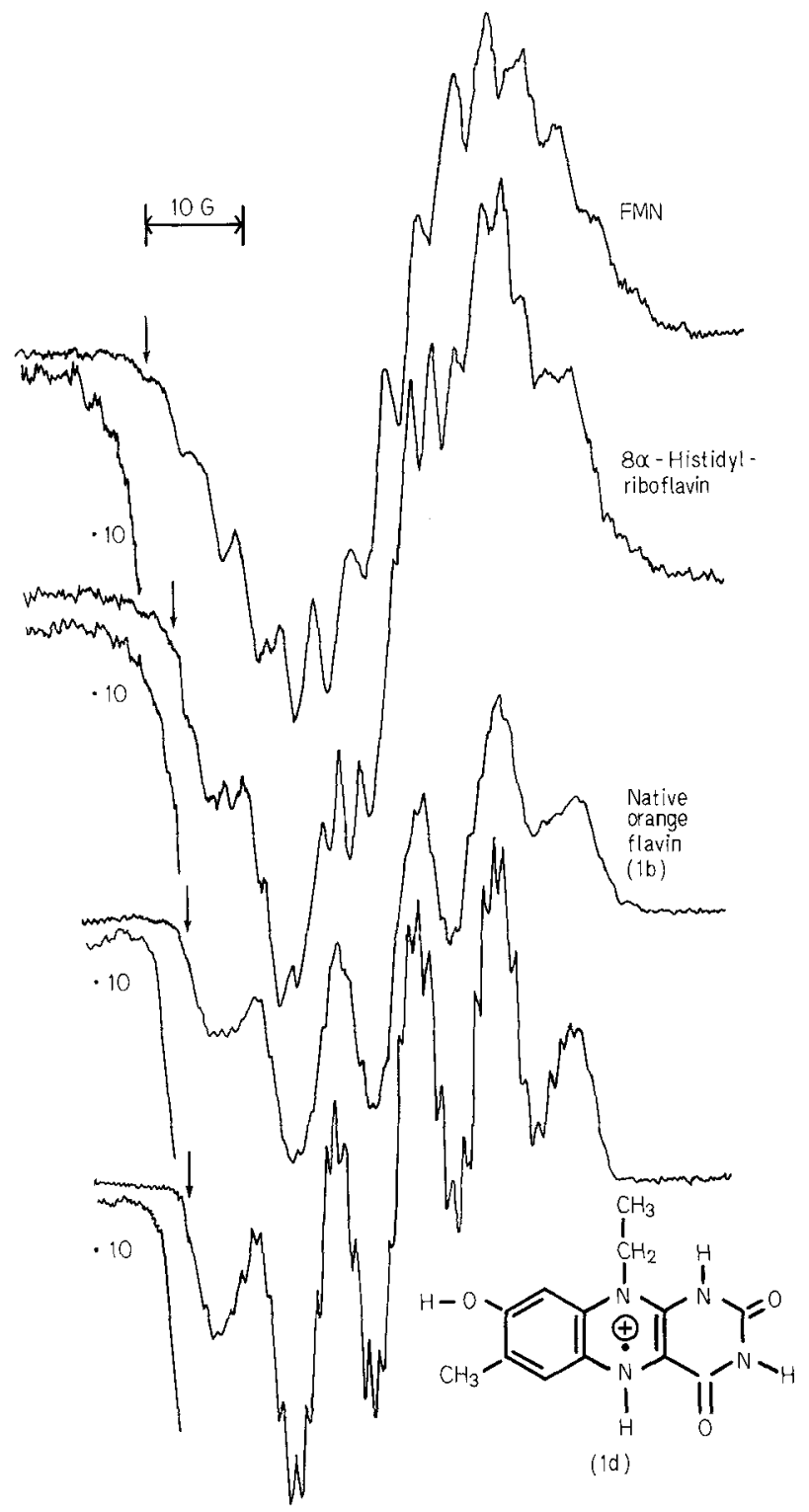

Fig. 2. EPR spectra of semiquinone cations of orange flavins and comparison with other flavosemiquinone cations. Spectra were recorded as described in Experimental Procedure. Arrows indicate the top of the outermost EPR line. The total width of the signal was taken to be twice the distance between the outermost line and the centre of the signal. No further wing lines were observed by increasing the gain 10 -fold

formulae). Both species could be in thermodynamic equilibrium, the position of which would be influenced by the solvent environment, and they are expected to exhibit different absorption spectra. For example, specific hydrogen bridges or charges at the binding site of an apo-flavoprotein could preferentially stabilize one of these tautomeric forms or the corresponding anion. Thus the orange flavins (and also 6-OHflavins [2]) could serve as sensitive indicators of the protein environment at the flavin binding site, and provide information not readily obtained with normal flavins (whose $\mathrm{p} K$ values are out of the physiological
$\mathrm{pH}$ range). A study covering the practical application of this point with several apoflavoproteins will be reported elsewhere [26]. It was therefore important to determine unambiguously the absorption properties of both tautomeric forms of compounds 1 by total synthesis of appropriate model compounds in which the electronic structure is 'blocked', by substitution for example. Similarly, by varying the substituents $\mathrm{R}_{1}, \mathrm{R}_{3}, \mathrm{R}_{4}$ and $\mathrm{R}_{5}$ (structural formulae in Table 2) the observed $\mathrm{p} K$ values could be assigned to the different functions on the isoalloxazine ring of compounds 1 .

The absorption spectrum of the neutral orange flavin $1, \mathrm{R}_{3}=\mathrm{H}$ (Table 2, cf. [4]) closely resembles the spectrum of the neutral 8-methoxyisoalloxazines 8 and 9 (Fig. 3, Table 2), but it is markedly different from the spectrum of the derivatives of the other possible tautomeric form, the "paraquinoid' 8-oxoisoalloxazine 15 (Fig.4). In contrast to our earlier assumption [4], and a proposal of Addink and Berends [6], it therefore appears that the 'phenolic' structure is the predominant tautomeric form of compounds 1 (Scheme 1, upper formula) and consequently that the $\mathrm{p} K$ at $\approx 4.8$ represents deprotonation of the hydroxyl function at C(8). Similarly, the $\mathrm{pH}$ dependence of the spectrum of compound 1 , $\mathrm{R}_{1}=\mathrm{C}_{2} \mathrm{H}_{5}$, in which $\mathrm{R}_{3}=\mathrm{H}$ or $\mathrm{CH}_{3}$ and $\mathrm{R}_{5}=\mathrm{OH}$ or $\mathrm{OCH}_{3}$ (Table 2), indicates that the $\mathrm{p} K$ at $\approx 11$ is due to the ionisation of the N(3)-H function.

The spectral features of normal flavins can be obtained from orange flavins by substitution of the (8)-OH group with electron-withdrawing functions such as acetyl (10) or tosylate (Fig. 1). The 'paraquinoid' flavin 15 in its neutral state shows a fairly resolved spectrum (Fig. 4) remarkably similar to those of the monoanions of compounds 1 (Fig. 1, curve 6); the band at $\approx 300 \mathrm{~nm}$ is red-shifted and increased in intensity, and at the same time the lowest energy band is decreased in intensity and also red-shifted (Fig. 4). Theoretical calculations (K. Weiss and R. Huber, personal communication) indeed confirm the assumption that the spectral type characterized by a high-intensity absorption around $475 \mathrm{~nm}$, and shown by compound 15 , and the anion of compounds 1 (Fig. 1 and 4), can be attributed to a 'paraquinoid' structure such as in compound 15 . The shift of the $\mathrm{p} K$ of protonation of the latter at $\mathrm{C}(8)=\mathrm{O}$ to 2.45 as compared to compounds $1(\mathrm{p} K=0.7)$ indicate that it has a pronounced dipolar character. The spectra of the cationic species of compounds $1\left(\lambda_{\max }=\right.$ $422 \mathrm{~nm}$, Table 2 and [4]), 8 ( $\lambda_{\max }=425 \mathrm{~nm}$, Fig. 3), $15\left(\lambda_{\max }=432 \mathrm{~nm}\right.$, Fig. 4$)$ and $11\left(\lambda_{\max }=422 \mathrm{~nm}\right.$, Fig. 5), indicate that the electronic structure of the four compounds are similar, and further that protonation of the neutral compound 1 occurs at $N(1)$, as in the case of normal isoalloxazines [22], and that protonation of compound 15 occurs at $\mathrm{C}(8)=\mathrm{O}$. It 
Table 2. Absorption maxima, absorption coefficients, fhorescence propenties and $\mathrm{p} \mathrm{K}$ values of 8 -substituted flavins and alloxazines Spectra in the $\mathrm{pH}$ range $2-11$ were measured at an ionic strength of $0.05-0.1 \mathrm{M}$. Values of $H_{0}$ were obtained with appropriately diluted sulphuric acid, and $\mathrm{pH}$ values above 11 were obtained with $\mathrm{NaOH}$. Fluorescence intensities are compared with the intensity of the fluorescence emission of lumiflavin 3-acetate at $\mathrm{pH} 7$ (excitation and emission light at 450 and $520 \mathrm{~nm}$ respectively) which was assigned a value of $100 \%$

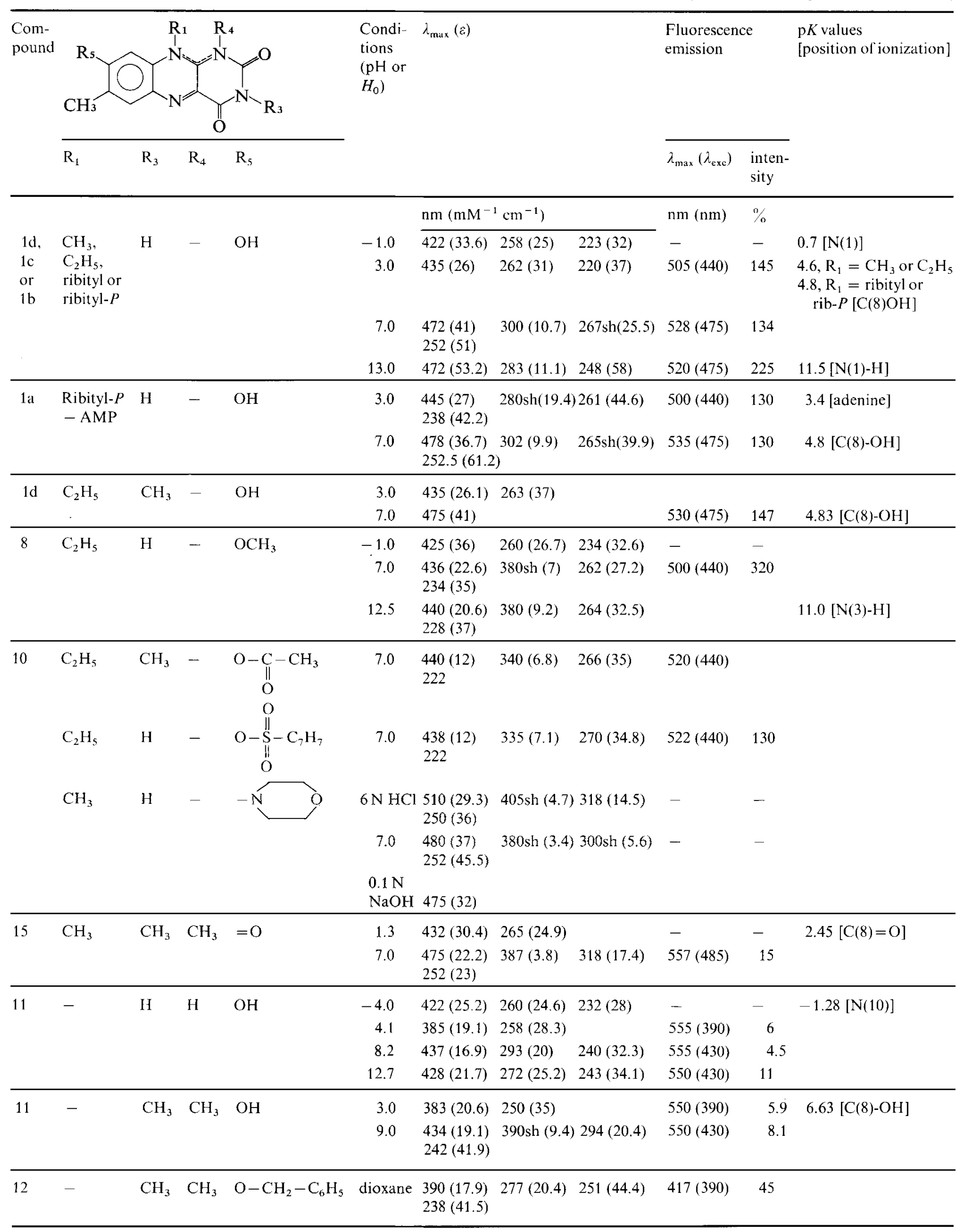




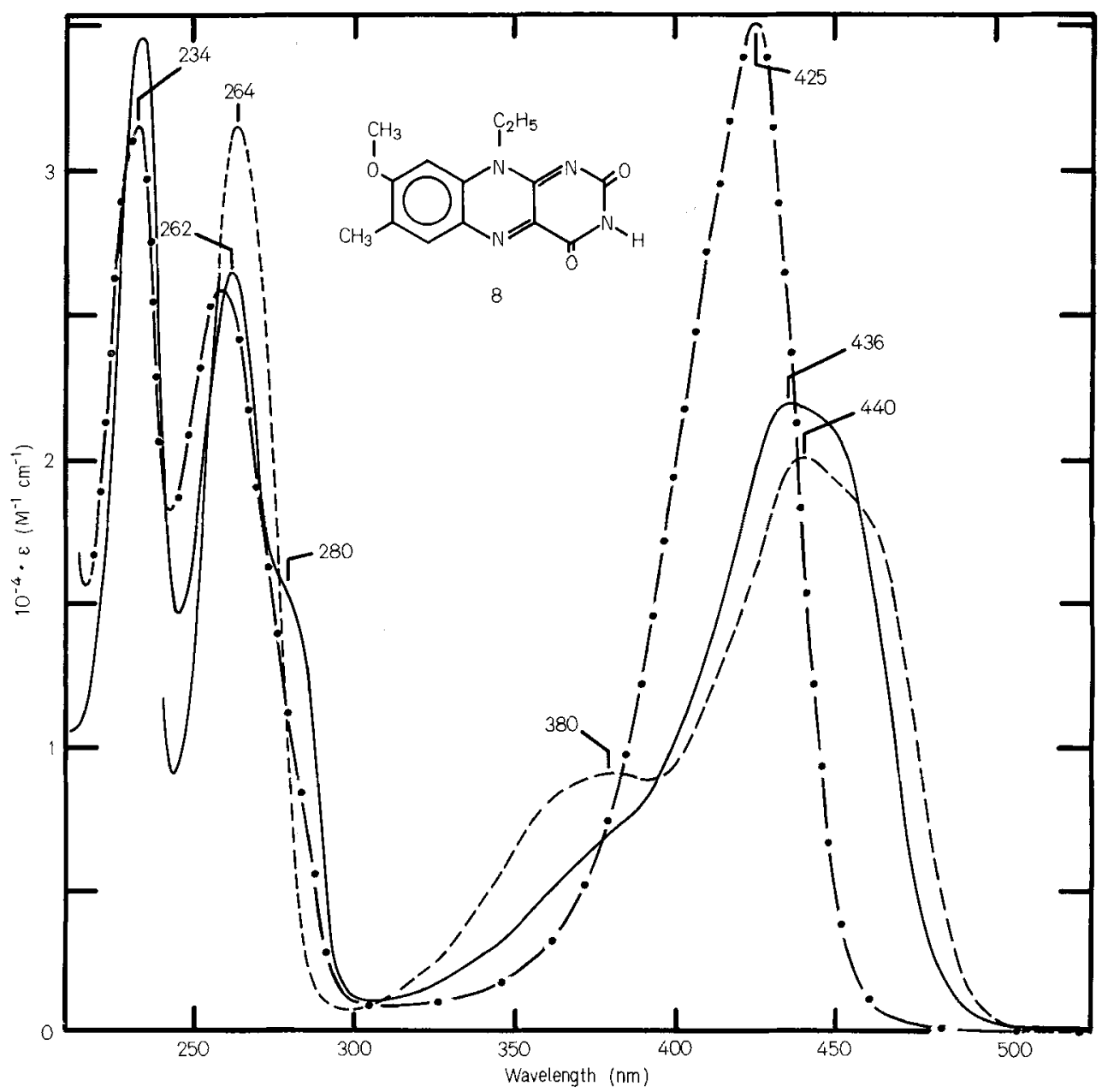

Fig. 3. Effects of pH on the spectrum of 8-methoxyflavin (8). The 8-methoxyflavin $8(20 \mu \mathrm{M})$ was dissolved in $0.1 \mathrm{M}$ buffers. $H_{0}=-1 ;(-) \mathrm{pH} 6.5 ;(---) \mathrm{pH} 12.5$

should be pointed out that, in contrast to the related 6-OH-flavins described earlier [2,27], the 8-hydroxyflavins 1 do not have any 'long-wavelength' absorptions in any of their ionization states.

Fig. 5 shows the spectra of the 8-OH-alloxazine $11\left(R_{3}, R_{4}=H\right)$, obtained by photodegradation of the native compounds $1, b, c$; they are closely similar in all ionization states to those of synthetic compound $11\left(\mathrm{R}_{3}, \mathrm{R}_{4}=\mathrm{H}\right)$. The $\mathrm{p} K$ of the $8-\mathrm{OH}$ group is shifted to 6.63 , by comparison with isoalloxazine 1 $(\mathrm{p} K \approx 4.7)$ and the $\mathrm{p} K$ of protonation of $\mathrm{N}(10)$ is lowered (to -1.28 ) by comparison with that of compounds $1(0.7)$ and normal flavin $(\approx 0[22])$.

\section{Fluorescence Properties}

8-OH-flavins fluoresce with emission intensities and maxima similar to those of normal flavins. This is in contrast to the 6-OH-flavins which have been reported to be not or only weakly fluorescent $[2,27]$. As with normal flavocoenzymes, the $\mathrm{pH}$ dependence of the fluorescence of the enzyme flavins 1 shows charac- teristic differences at the FAD (1a) and FMN (1b) levels. This $\mathrm{pH}$ dependence (Fig. 6) also reflects the ionisation state of the $\mathrm{C}(8)$ and $\mathrm{N}(3)$ functions and is a useful tool for differentiating between these modified flavins and normal flavins.

The complete quenching of the emission at low $\mathrm{pH}$ (apparent $\mathrm{p} K \approx 2$ ) does not coincide with the $\mathrm{p} K$ of protonation determined by light absorption measurements $(\mathrm{p} K=0.7)$; it probably reflects dynamic proton quenching as is the case with normal flavins [28]. As with FAD, deprotonation of the adenine nucleus in 8-OH-FAD (1a) leads to a quenching of the fluorescence $(\mathrm{p} K \approx 3.4)$, but concomitant with the first ionization of the 8-OH isoalloxazine moiety, the original emission intensity is restored. These effects are not observed with 8-OH-FMN (1b) and it therefore appears that 'hairpin' complexation in 8-OH-FAD and consequent fluorescent quenching only occurs between the uncharged subunits. The $\mathrm{p} K$ at 11.5 , which leads to a strong fluorescence increase, reflects deprotonation at $\mathrm{N}(3)-\mathrm{H}$ to form the dianion of compound 1 . This is in contrast to the 


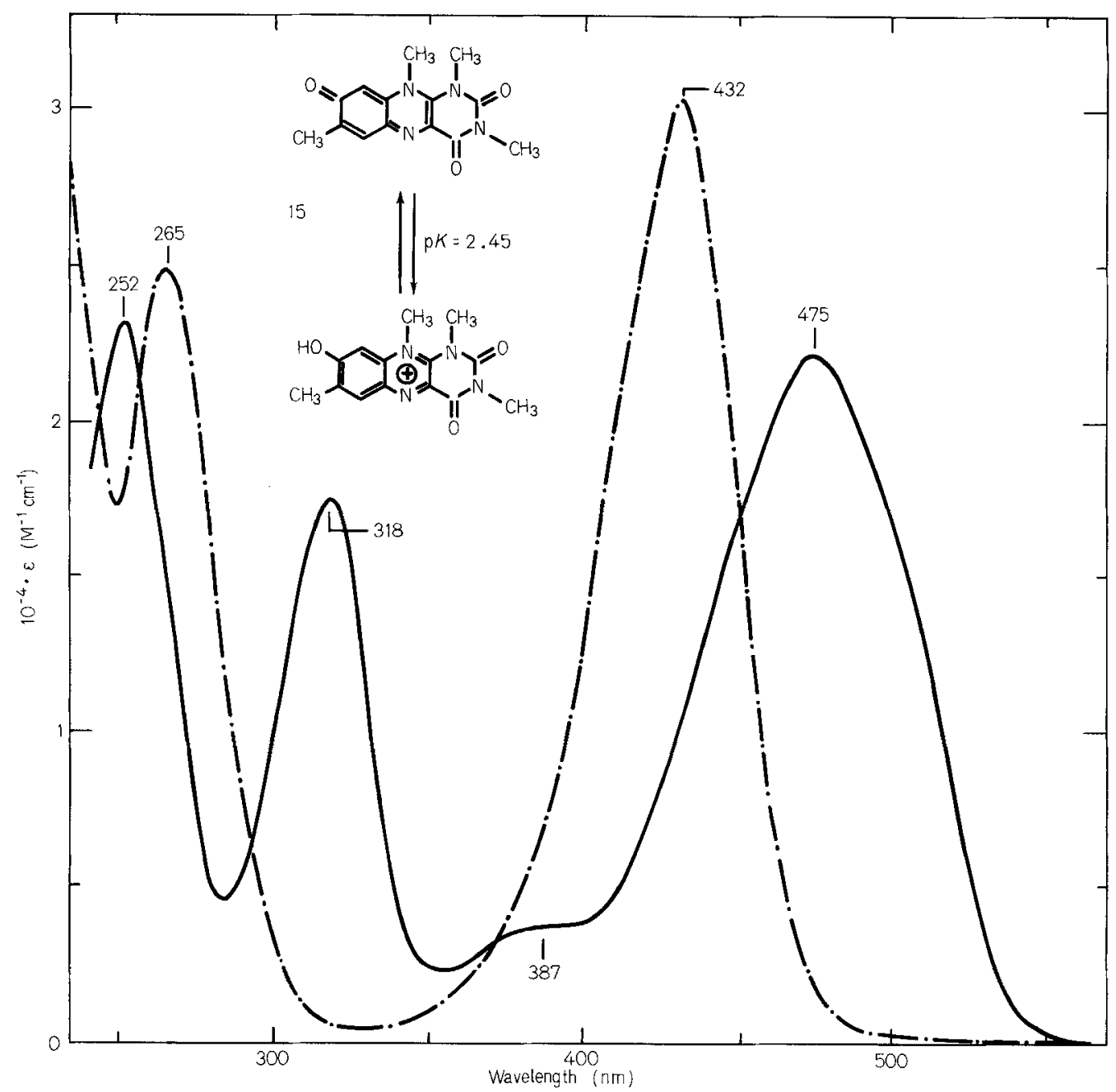

Fig. 4. Absorption spectra of the 'paraquinoid' flavin (15) in the neutral (___-) and cationic (.__. forms

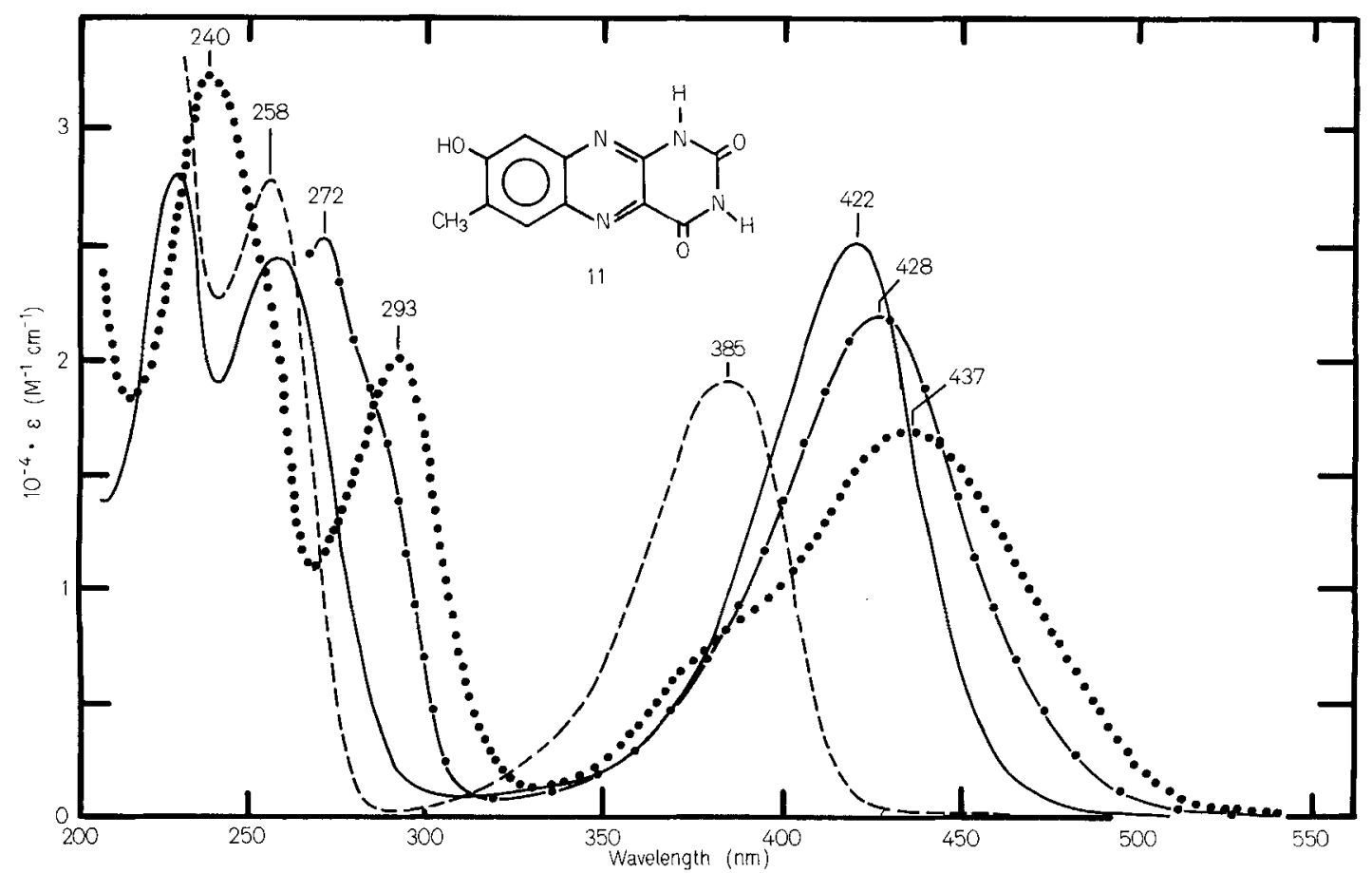

Fig. 5. $p H$-dependence of the electronic spectrum of the 8 -hydroxyalloxazine $\left(11, R_{3}, R_{4}=H\right) .(-) H_{0}=-4 ;(-\cdots)$ pH $4.1 ;(\cdots)$ $\mathrm{pH} 8.2 ;(\bullet-) \mathrm{pH} 12.7$ 


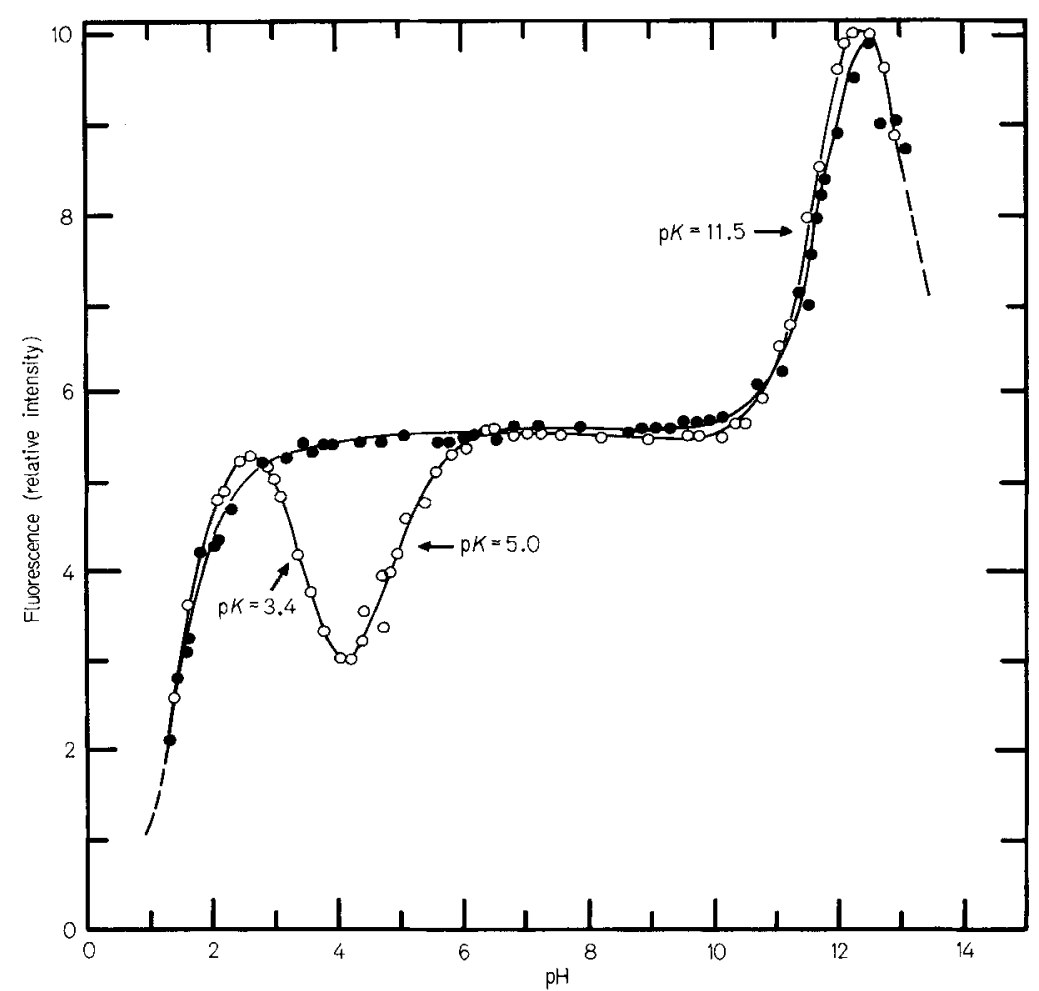

Fig.6. pH-dependence of the fluorescence intensity of 8-OH-FAD (la) $(\mathrm{O}-\mathrm{O})$ and 8-OH-FMN (Ib) (- - - The $\mathrm{pH}$ of an unbuffered solution of $8 . \mathrm{OH}-\mathrm{FAD}(1 \mathrm{a})(2 \mu \mathrm{M})$ in $0.05 \mathrm{M} \mathrm{NaCl}(2 \mathrm{ml})$ was adjusted by addition of small amounts of solid phosphate salts, citric acid, potassium carbonate, potassium hydroxide and sulphuric acid. Data for 8-OH-FMN (1b) were obtained under similar conditions but after addition of phosphodiesterase (Naja naja venom) to a solution of 8-OH-FAD (1a). The wavelength of the exciting light was $443 \mathrm{~nm}$, an isosbestic point between the absorption spectra of the neutral and anionic forms of the chromophore; fluorescence intensities were measured at $520 \mathrm{~nm}$, the isosbestic point between the corresponding emission spectra. Each point in the figure represents a single measurement

case with normal flavins in which ionization of $\mathrm{N}(3)$-H leads to complete quenching, but similar to the effect observed with the lumichrome series [29]. The fluorescence of the isoalloxazines 11 and 12 is anomalous: whereas the emission of the 8-O-benzoyl compound $\left(12, \mathrm{R}_{2}=\mathrm{CH}_{2}-\mathrm{C}_{6} \mathrm{H}_{5}\right)$ in toluene $\left(\lambda_{\max }=\right.$ $417 \mathrm{~nm}$ ) has the expected overlap with the lowest energy transition $\left(\lambda_{\max }=390 \mathrm{~nm}\right)$ (Table 2$)$, in water/ dioxane $(9 / 1, v / v)$ it is very broad and maximal at $450 \mathrm{~nm}$. Further, although the fluorescence excitation spectra of compound $11\left(\mathrm{R}_{3}=\mathrm{R}_{4}=\mathrm{CH}_{3}\right)$ in its neutral ( $\mathrm{pH} 3$ ) and monoanionic $(\mathrm{pH}$ 9) forms differ and correspond with the different absorption spectra, the fluorescence emission spectra are very similar in shape and both have a maximum at $550 \mathrm{~nm}$ (Fig. 7). It thus appears that, independently from the ionization of the ground state, the emitting species is the excited anion of compound 11, and consequently that the $\mathrm{pK}$ of the $\mathrm{C}(8)-\mathrm{OH}$ group in the excited state is lowered by at least 3 units by comparison with the $\mathrm{p} K$ of the ground state. This observation is in accord with an extensive transfer of charge from the $\mathrm{C}(8)$ position of the alloxazine system upon excitation [30].

\section{Binding of 8-OH-flavins to Apoflavoproteins}

The apoproteins of D-amino acid oxidase [13] and electron-transferring flavoprotein [5] bind 8-OHFAD (1a) and apoflavodoxin from $P$. elsdenii binds 8 -OH-FMN (1b). The spectral properties of these complexes differ from each other and from those of the free flavins, and they provide useful information about the flavin-binding sites in each protein.

When 8-OH-FAD (1a) is bound to D-amino acid oxidase, the absorption band in the visible region is shifted to the red, reduced in intensity and resolved (cf. [31]) to give shoulders on each side of the maximum (Fig. 8), and the band at $\approx 300 \mathrm{~nm}$ is red-shifted to $322 \mathrm{~nm}$. At the same time the fluorescence emission of the flavin is increased by about $30 \%$. The dissociation constant for the 8-OH-flavin - protein complex $(0.105 \mu \mathrm{M})$, determined by spectrophotometric titration, is lower than that for the binding of normal FAD to the apoprotein $(0.22 \mu \mathrm{M})$ [13]. However, the complex is devoid of catalytic activity in the standard assay [12] for D-amino acid oxidase. Addition of benzoate to the complex causes a loss of resolution in the visible spectrum but does not alter the fluores- 


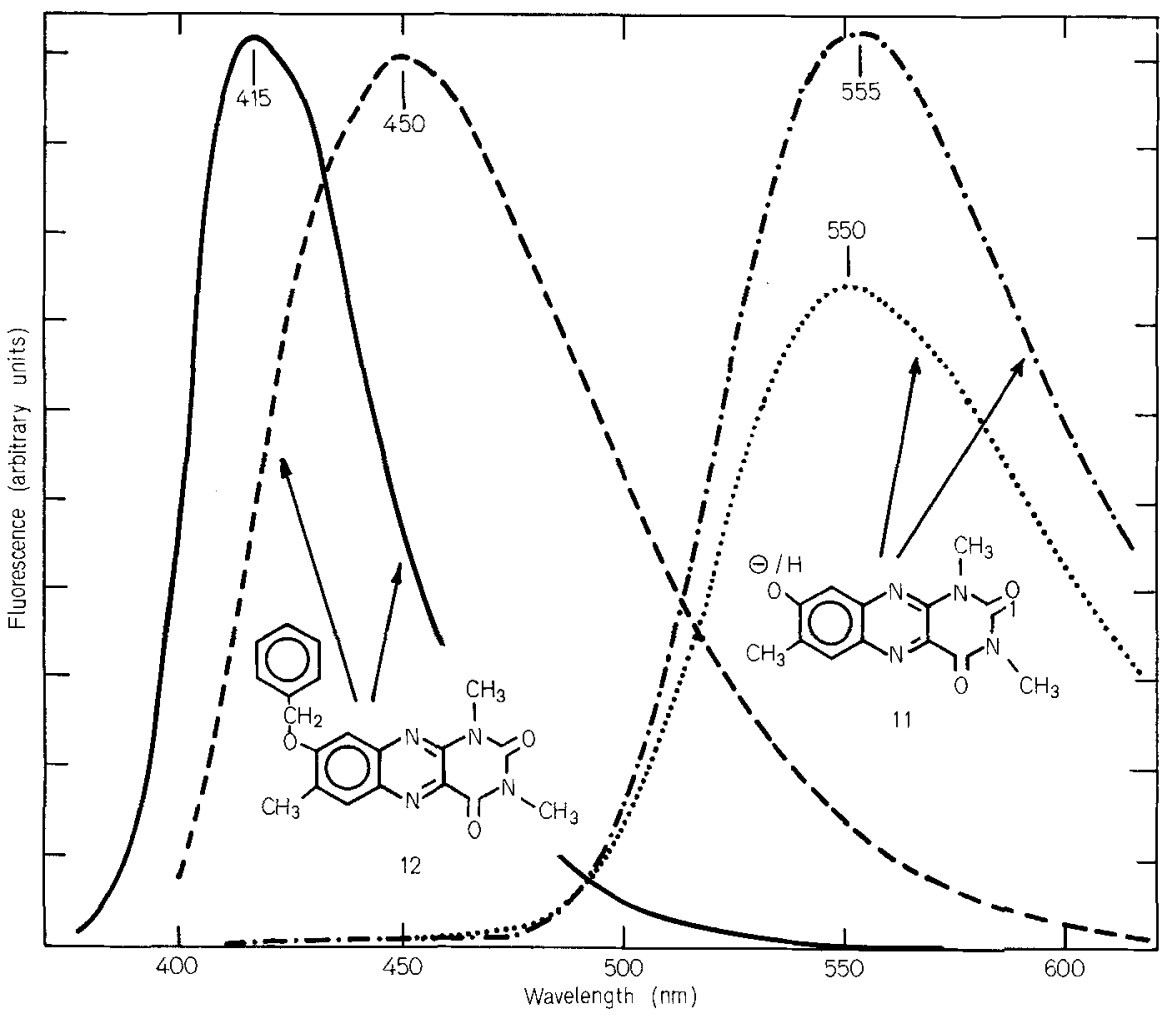

Fig. 7. Effects of $\mathrm{pH}$ and solvent on the fluorescence emission spectra of the alloxazines 11 and 12 . Curve (--): 1,3,7-trimethyl-8-benzyloxyalloxazine $\left(12, \mathrm{R}_{2}=\mathrm{CH}_{2}-\mathrm{C}_{6} \mathrm{H}_{5}\right)(19 \mu \mathrm{M})$ in toluene (excitation at $\left.390 \mathrm{~nm}\right)$. Curve $\left({ }_{--}\right)$: the same compound $(2.7 \mu \mathrm{M})$ in water/ dioxane $(9 / 1, \mathrm{v} / \mathrm{v}$; excitation at $390 \mathrm{~nm})$. Curve $(\longrightarrow)$ ) the neutral lumichrome $11\left(\mathrm{R}_{3}, \mathrm{R}_{4}=\mathrm{CH}_{3}\right)$ at $\mathrm{pH} 3(30 \mu \mathrm{M}$; excitation at $390 \mathrm{~nm})$ in $0.05 \mathrm{M} \mathrm{NaCl}$. Curve $(\cdots) \cdot)$ : the anion of alloxazine $11\left(\mathrm{R}_{3}, \mathrm{R}_{4}=\mathrm{CH}_{3}\right)$ at $\mathrm{pH} 8(30 \mu \mathrm{M}$; excitation at $430 \mathrm{~nm})$ in $0.05 \mathrm{M} \mathrm{NaCl}$. The relative fluorescence intensities by comparison with lumiflavin-3-acetate at $\mathrm{pH} 7(4.8 \mu \mathrm{M}$; excitation at $450 \mathrm{~nm}$ and emission at $520 \mathrm{~nm})$ were $0.46,0.6,0.059$ and 0.081 for alloxazines $12\left(\mathrm{R}_{2}=\mathrm{CH}_{2}-\mathrm{C}_{6} \mathrm{H}_{5}\right)$ in toluene and water/dioxane and $11\left(\mathrm{R}_{3}, \mathrm{R}_{4}=\mathrm{CH}_{3}\right)$ at $\mathrm{pH} 3$ and $\mathrm{pH} 8$ respectively

cence intensity. It is notable that these spectroscopic changes are quite different from those observed with native enzyme; the bound flavin is $80 \%$ less fluorescent than free FAD, the absorption spectrum retains its unresolved character, and is converted to the resolved type after the addition of benzoate [31].

When $8-\mathrm{OH}-\mathrm{FMN}(1 \mathrm{~b})$ is bound by apoflavodoxin at $\mathrm{pH} 8.1$, the intensity of the single visible absorption band is decreased by $22 \%$ and the maximum is redshifted to $482 \mathrm{~nm}$ (Fig. 9). The intensity of the band decreases further when the $\mathrm{pH}$ is lowered to 4.9 , the maximum moves to $460 \mathrm{~nm}$ and shoulders develop on each side of the maximum. The $\mathrm{p} K$ for this change is at 6.1 and is therefore shifted by comparison with the $\mathrm{p} K$ of the free $8-\mathrm{OH}$-flavin. A similar $\mathrm{p} K$ shift has previously been observed when $6-\mathrm{OH}-\mathrm{FMN}$ is bound to apoflavodoxin [2]. The complex of apoflavodoxin with 8-OH-FMN (1b) is non-fluorescent in both ionization states in contrast to the complex of apo-D-amino acid oxidase with 8-OH-FAD (1a). The extra negative charge provided by $8-\mathrm{OH}-\mathrm{FMN}$ - apoflavodoxin causes a tighter binding of the protein to DEAE-cellulose and allows the complex to be separated from native flavodoxin when a mixture is chromatographed at $\mathrm{pH} 8$.
The complex is completely reduced by an equimolar amount of sodium dithionite; an intermediate, which is presumed to be the semiquinone, develops during anaerobic titrations with this reductant. At $\mathrm{pH} 5.8$, the intermediate shows a high band of absorption at $580 \mathrm{~nm}\left(\varepsilon_{580 \mathrm{~nm}}=9500 \mathrm{M}^{-1} \mathrm{~cm}^{-1}\right)$ and it is produced almost quantitatively (Fig. 10). Much less of the intermediate is formed at $\mathrm{pH} 8$, and the long-wavelength maximum in its spectrum is shifted to $585 \mathrm{~nm}$, and in addition it shows a shoulder at $650 \mathrm{~nm}$. Since the anionic semiquinone of normal FMN is not stabilized by native flavodoxin even at $\mathrm{pH}$ values above 10 , the differences between these two semiquinone spectra of 8-OH-FMN - apoflavodoxin probably reflect the ionization at $\mathrm{C}(8)-\mathrm{OH}$ of the flavin radical itself. The spectra of both forms of the intermediate differ from the spectrum of the normal neutral flavin semiquinone of this flavodoxin (Fig. 10). Aeration of the fully reduced complex causes a rapid reoxidation to the intermediate, followed by its further slow reoxidation (pseudo-first-order rate constant at $\mathrm{pH} 6.5$ and $20^{\circ} \mathrm{C}=0.74 \mathrm{~min}^{-1}$ ).

The flavodoxin complex is biochemically active and replaces native flavodoxin as an electron carrier in the phosphoroclastic oxidation of pyruvate [10]. 


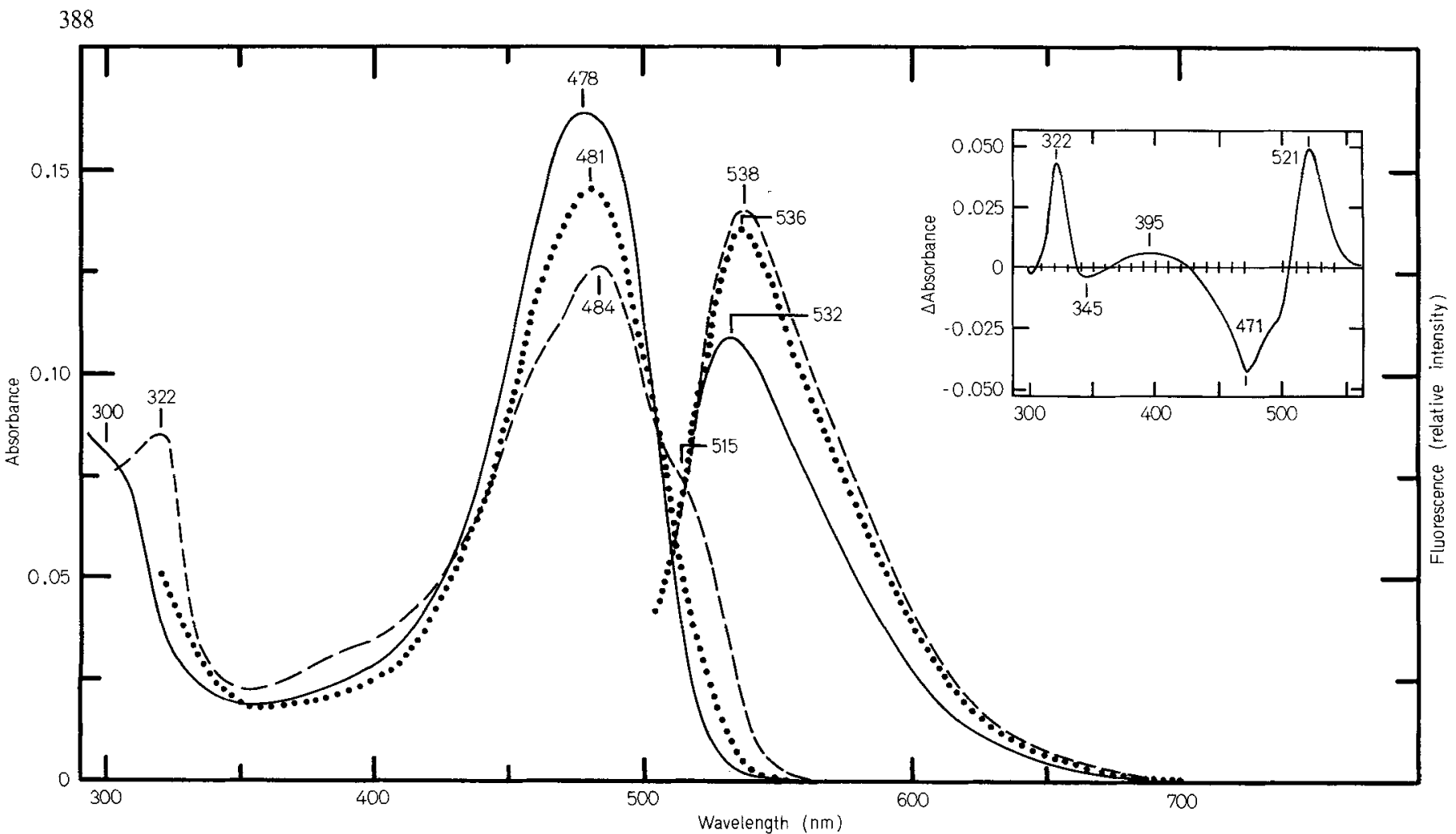

Fig. 8. Spectral properties of 8-OH-FAD (1a) bound to apo-D-amino acid oxidase. A solution of 8-OH-FAD (1a) $(9 \mu \mathrm{M})$ in $0.1 \mathrm{M}$ pyrophosphate buffer, $\mathrm{pH} 8.5(-)$ was treated with increments of apo-D-amino acid oxidase $(0.3 \mathrm{mM})$ in the same buffer. (---) After addition of apo-D-amino acid oxidase to a final concentration of $20 \mu \mathrm{M} ;(\cdots \cdots)$ after the subsequent addition of sodium benzoate to $2 \mathrm{mM}$. The inset shows the difference spectrum between 8-OH-FAD - apo-D-amino-acid-oxidase and its complex with benzoate

At non-saturating concentrations of the electron carrier, the activity of $8-\mathrm{OH}-\mathrm{FMN} \cdot$ apoflavodoxin is $78 \%$ of the activity of an equivalent amount of native flavodoxin.

Comparison of the spectra of the protein-bound orange flavins with the spectra of the models indicates that the protein environments at the coenzyme binding sites differ. The spectra of 8-OH-FAD - apo-Damino-acid-oxidase (Fig. 8), 8-OH-FAD - apo-electron-transferring-flavoprotein [5], and 8-OH-FMN - apo-lactate-oxidase [26] resemble that of the neutral form of "paraquinoid" flavin 15 (Fig. 4) which also shows some resolution, low intensity in the band in the visible region and a red shift of about $20 \mathrm{~nm}$ in the $300-\mathrm{nm}$ band (compare with curve 6 in Fig. 1). This resemblance suggests that the electronic distribution of the 8-OH-flavin in these enzymes is similar to that in compound 15 , and that in the enzymes the flavin is in the 'paraquinoid' rather than in the 'phenolic' form ( $c f$. formulae 1, Scheme 1). As was pointed out previously for 6-OH-FAD - apo-electrontransferring-flavoprotein [2], a positively charged group close to the $\mathrm{N}(1)-\mathrm{C}(2)=\mathrm{O}$ of the coenzyme might induce these spectra effects, and it would also explain why the negatively charged 8-OH-FAD (1a) is bound more tightly than FAD to apo-D-amino acid oxidase. A positive charge near the flavin of D-amino acid oxidase has been proposed earlier to explain the stability of the anionic semiquinone in this enzyme and also its reactions with sulphite and benzoate [32].

The spectrum of the complex of 8-OH-FMN (1b) and apoflavodoxin at $\mathrm{pH} 4.9$ (shoulder $440 \mathrm{~nm}$, maximum $460 \mathrm{~nm}$, Fig.9) resembles the spectrum of compound 8 in its neutral form (maximum $436 \mathrm{~nm}$, shoulder $455 \mathrm{~nm}$, Fig. 3), and at pH 7.8 the spectrum of the complex is similar to the monoanion of compounds 1 (Fig.1, curve 6). It therefore seems likely that the "phenolic' structure 1a of $8-\mathrm{OH}-\mathrm{FMN}$ is stabilized in the complex with apoflavodoxin. A negative charge close to $\mathrm{N}(3)-\mathrm{C}(4)=\mathrm{O}$, as observed by $\mathrm{X}$-ray crystallography of a related flavodoxin [33], and/or the hydrophobic protein environment are probably responsible for the shift of $\mathrm{p} K$ from 4.8 to 6.1 .

These and other [2] preliminary results on the properties of protein-bound hydroxyflavins indicate their potential usefulness as probes of the charge distribution in the catalytic centres of flavoproteins; a systematic investigation of the properties of their complexes with other apoflavoproteins will be published elsewhere [26].

\section{Formation of 8-OH-FAD \\ in Electron-Transferring Flavoprotein}

Whitfield and Mayhew [5] have shown that electron-transferring flavoprotein from P. elsdenii con- 


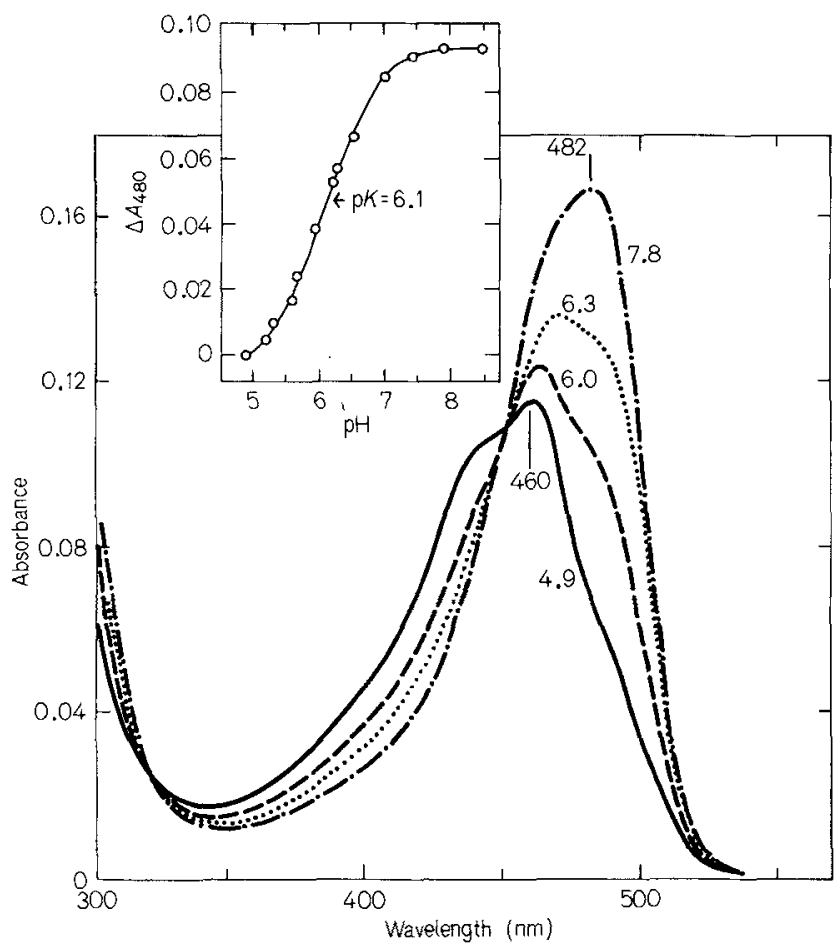

Fig. 9. Effect of $\mathrm{pH}$ on the spectrum of $8-\mathrm{OH}-\mathrm{FMN}$ - apoflavodoxin. A solution of $4.3 \mu \mathrm{M} 8-\mathrm{OH}-\mathrm{FMN}(1 \mathrm{~b})$ and $7.3 \mu \mathrm{M}$ apoflavodoxin in $2 \mathrm{ml} 0.05 \mathrm{M} \mathrm{NaCl}$ and $0.01 \mathrm{M}$ potassium phosphate buffer, pH 7.8, was titrated first to $\mathrm{pH} 4.9$ by the incremental addition of solid citric acid, and then to $\mathrm{pH} 8.5$ by addition of $2 \mathrm{~N} \mathrm{NaOH}$. Absorption spectra and $\mathrm{pH}$ were recorded after each addition. The inset shows a plot of the change in absorption at $480 \mathrm{~nm}$ versus $\mathrm{pH}$ tains two molecules of flavin linked non-covalently to two protein subunits of different molecular weight. Most of the flavin in the enzyme is FAD, but all preparation contain at least traces of 6-OH-FAD and 8-OH-FAD (1a) [5]. The discovery of the hydroxyflavins and the observation that enzyme molecules which contain them do not transfer electrons to butyryl-CoA dehydrogenase, the natural electron acceptor for electron-transferring flavoprotein, prompted speculation about their origin and function in the enzyme [2,5]. However, subsequent analysis of crude extracts of the strict anaerobe $P$. elsdenii has shown that neither of the hydroxyflavins can be detected until after exposure of the extracts to air (C. D. Whitfield, private communication; I. Dekker and S. G. Mayhew, unpublished). This suggests that the modified flavins are not normal constituents in the bacterium, and that they are probably formed in electron-transferring flavoprotein during its isolation. Conditions for generating the hydroxyflavins from unmodified FAD in purified electron-transferring flavoprotein have not yet been found.

Although present evidence suggests that the hydroxyflavins have no physiological importance in $P$. elsdenii, the mechanism of their formation and the special properties of electron-transferring flavoprotein (and also glycollate oxidase from pig liver [2]) which evidently favour production of hydroxy derivatives of the coenzyme, remain of interest. A reaction which might be related to the reaction that gives

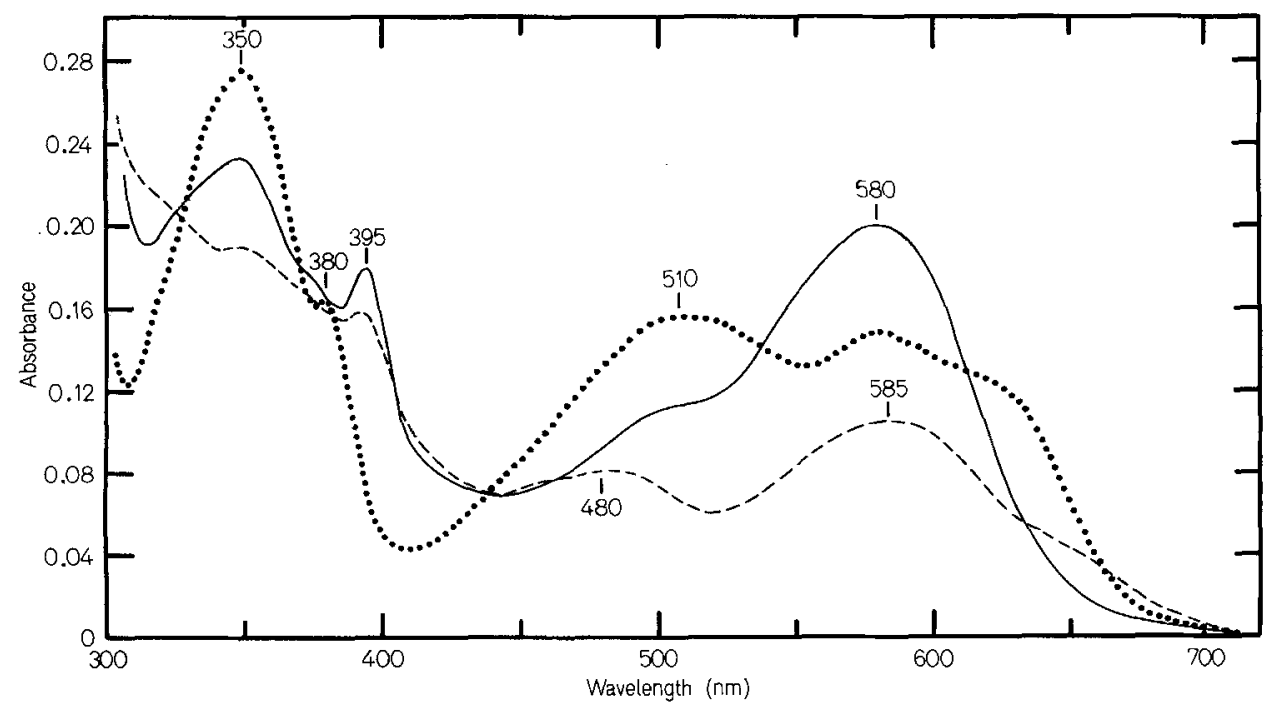

Fig. 10. Absorption spectra of the intermediates formed during the reduction of $8-O H-F M N$ apoflavodoxin and native flavodoxin. Increments of sodium dithionite $(2.6 \mathrm{mM})$ in sodium pyrophosphate, $\mathrm{pH} 8.5$, were added under anaerobic conditions [8] to $2.5 \mathrm{ml}$ of $8-\mathrm{OH}-\mathrm{FMN}$ . apoflavodoxin $(24 \mu \mathrm{M})$ in either $0.1 \mathrm{M}$ Tris-HCl buffer, $\mathrm{pH} 8.0,(--)_{-}$or $0.05 \mathrm{M}$ sodium acetate buffer, $\mathrm{pH} 5.8(--)$, until the maximum amount of intermediate was observed (approximately $0.5 \mathrm{~mol}$ of dithionite per mol of flavin). (....) The spectrum of the blue flavin semiquinone of native flavodoxin $(34 \mu \mathrm{M})$ in $0.1 \mathrm{M}$ sodium pyrophosphate buffer, pH 8.3 
rise to 8-OH-FAD (1a) in the enzyme has been observed in a model system. Addink and Berends [6] report that 6,7-dihydro-7,8-dimethylisoalloxazine can be oxidized by oxygen in alkaline medium to 6,7-dihydro-7-methyl-8-hydroxyisoalloxazine in good yield. No such oxidative removal of the $\mathrm{C}(8)-\mathrm{CH}_{3}$ group has ever been reported for 'fully aromatic' (iso)alloxazines, but recently it has been proposed that adducts at positions $\mathrm{C}(6)$ or $\mathrm{C}(8)$ might arise as intermediates during the reoxidation of reduced flavins [34] or as side reactions during catalysis [2]. It is possible that such intermediates might react further with oxygen in a way similar to the reaction described by Addink and Berends [6].

As described above, the spectroscopic properties of 8-OH-FAD - apo-electron-transferring-protein (and 8-OH-FAD - apo-D-amino-acid-oxidase) suggest that the electronic system of the isoalloxazine is polarized towards positions $\mathrm{N}(1)-\mathrm{C}(2)=\mathrm{O}$ through the effect of a positive charge or a hydrogen bridge (structure A). Thus abstraction of a proton at $\mathrm{C}(8)-\mathrm{CH}_{3}$ of FAD to yield $B$ should be favoured.

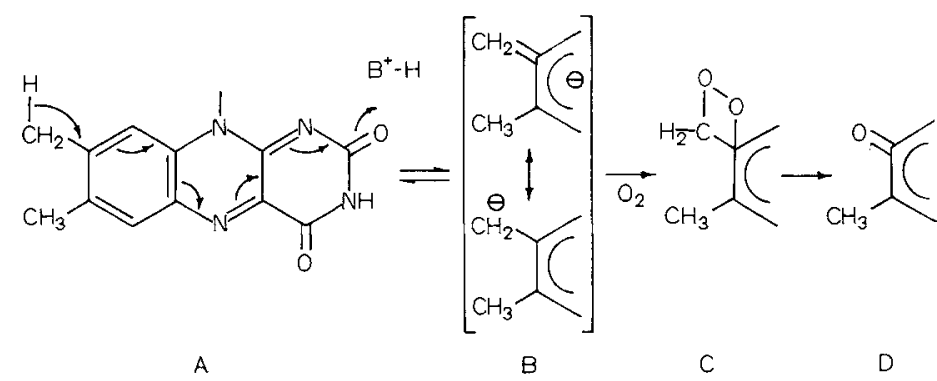

A reaction of oxygen with a species such as $B$ could lead to $C$, which in turn would decay to a fragment such as D. Similar reactions are known in organic chemistry and have been proposed for the oxidation of some olefinic compounds by oxygen (see several articles in [35]).

We wish to thank Dr V. Massey for providing advice and facilities. This work was supported by USPHS Grant GM 11106 to Dr V. Massey and a grant from Schweizerische Naturforschende Gesellschaft to S. Ghisla.

\section{REFERENCES}

1. Singer, T. P. \& Edmondson, D. (1974) FEBS Lett. 42, 1-14.

2. Mayhew, S. G., Whitfield, C. D., Ghisla, S. \& Schuman-Jörns, M. (1974) Eur. J. Biochem. 44, 579-591.

3. Mayhew, S. G. \& Massey, V. (1971) Biochim. Biophys. Acta, $235,303-310$.

4. Ghisla, S. \& Mayhew, S. G. (1973) J. Biol. Chem. 248, 65686570 .
5. Whitfield, C. D. \& Mayhew, S. G. (1974) J. Biol. Chem. 249, $2801-2810$ and $2811-2815$.

6. Addink, R. \& Berends, W. (1974) Tetrahedron, 30, 75-78.

7. Polyakova, N. A., Tul'chinskaya, L. S., Zapesochnaya, L. G. \& Berezovskii, V. M. (1972) Zh. Obshch. Khim. 42, 465-468.

8. Foust, G. P., Burleigh, D. B., Jr, Mayhew, S. G., Williams, C. H., Jr \& Massey, V. (1969) Anal. Biochem. 27, 530-535.

9. Casola, L., Brumby, P. E. \& Massey, V. (1966) J. Biol. Chem. 241, 4977-4984.

10. Mayhew, S.G.\&Massey, V. (1969) J. Biol.Chem.244,794- 802. 11. Mayhew, S. G. (1971) Biochim. Biophys. Acta, 235, 289-302.

12. Brumby, P. E. \& Massey, V. (1968) Biochem. Prep. 12, 29.

13. Massey, V. \& Curti, B. (1966) J. Biol. Chem. 24I, 3417-3423.

14. Beilsteins Handbuch der Organischen Chemie, (1930) 4th Ed., Vol. 13, p. 574, Julius Springer, Berlin.

15. Lambooy, T. P. (1967) Heterocyclic Compounds (Elderfield, R. C., ed.) pp. 159-162, Wiley, New York.

16. Hemmerich, P. (1964) Helv. Chim. Acta, 47, 464-475.

17. Hemmerich, P., Prijs, B. \& Erlenmeyer, H. (1959) Helv. Chim. Acta, 42, 1604-1611.

18. Blitz, H. \& Witteck, H. (1921) Ber. Dtsch. Chem. Ges. 54, $1035-1058$

19. Bruckman, G. \& Isaacs, S. D. (1949) J. Am. Chem. Soc. 71 , $390-392$.

20a. Dudley, K. H. \& Hemmerich, P. (1967) Helv. Chim. Acta, $50,355-363$.

20b. Jefcoate, C. R., Ghisla, S. \& Hemmerich, P. (1971) J. Chem. Soc. C. $1689-1694$.

21. Bessey, O. A., Lowry, O. H. \& Love, R. H. (1949) J. Biol Chem. 180,755-769.

22. Hemmerich, P., Veeger, C. \& Wood, H. C. S. (1965) Angew. Chem. In. Ed. 4, 671-688.

23. Bullock, F. J. \& Jardetzky, O. (1965) J. Am. Chem. Soc. 30, $2056-2057$.

24. Hemmerich, P., Prijs, B. \& Erlenmeyer, H. (1959) Helv. Chim. Acta, 42, 2164-2177.

25. Salach, J., Walker, W., Singer, T. P., Ehrenberg, A., Hemmerich, P., Ghisla, S. \& Hartmann, U. (1972) Eur. J. Biochem. $26,267-278$.

26. Ghisla, S., Massey, V. \& Mayhew, S. G. in Proc. 5th Int Symp. on Flavins and Proteins (Singer, T. P., ed.) in press.

27. Schöllnhammer, G. \& Hemmerich, P. (1974) Eur. J. Biochem. $44,561-577$.

28. Lasser, N. \& Feitelson, J. (1973) J. Phys. Chem. 77, $1011-$ 1016.

29. Müller, F. \& Dudley, K. H. (1971) Helv. Chim. Acta, 54, $1487-1497$.

30. Lhoste, J. M. (1971) Proc. 1st Eur. Biophys. Congr. (Broda, E., Locker, A. \& Springer-Lederer, H., eds) pp. $221-224$, Verlag Wiener Medical Academy.

31. Massey, V. \& Ganther, H. (1965) Biochemistry, 4, 1161-1173.

32. Massey, V., Müller, F., Feldberg, R., Schuman, M., Sullivan, P. A., Howell, L. G., Mayhew, S. G., Matthews, R. G. \& Foust, G. P. (1969) J. Biol. Chem. 244, 3999-4006.

33. Burnett, R. M., Darling, G. D., Kendall, D. S., LeQuesne, M. E., Mayhew, S. G., Smith, W. W. \& Ludwig, M. L. (1974) J. Biol. Chem. 249, 4383-4392.

34. Hemmerich, P. \& Müller, F. (1973) Ann. N.Y. Acad. Sci. 212 $13-26$.

35. Swern, D. (1972) Organic Peroxides, vol. I-III, Wiley-Interscience, New York.

36. Walker, W.H., Singer, T.P., Ghisla, S. \& Hemmerich,P. (1972) Eur. J. Biochem. 26, 279-289. 